\title{
Invited review: Genetics and modeling of milk coagulation properties
}

\author{
G. Bittante, M. Penasa, ${ }^{1}$ and A. Cecchinato \\ Department of Agronomy, Food, Natural Resources, Animals and Environment (DAFNAE), University of Padova, Viale dell'Università 16, \\ 35020 Legnaro (PD), Italy
}

\begin{abstract}
Milk coagulation properties (MCP) are conventionally measured using computerized renneting meters, mechanical or optical devices that record curd firmness over time $\left(\mathrm{CF}_{\mathrm{t}}\right)$. The traditional MCP are rennet coagulation time (RCT, min), curd firmness $\left(\mathrm{a}_{30}, \mathrm{~mm}\right)$, and curd-firming time $\left(\mathrm{k}_{20}, \mathrm{~min}\right)$. The milk of different ruminant species varies in terms of $\mathrm{CF}_{\mathrm{t}}$ pattern. Milk from Holstein-Friesian and some Scandinavian cattle breeds yields higher proportions of noncoagulating samples, samples with longer RCT and lower $\mathrm{a}_{30}$, and samples for which $\mathrm{k}_{20}$ is not estimable, than does milk from Brown Swiss, Simmental, and other local Alpine breeds. The amount, proportion, and genetic variants (especially $\kappa$-casein) of milk protein fractions strongly influence MCP and explain variable proportions of the observed differences among breeds and among individuals of the same breed. In addition, other major genes have been shown to affect MCP. Individual repeatability of MCP is high, whereas any herd effect is low; thus, the improvement of MCP should be based principally on selection. Exploitable additive genetic variation in MCP exists and has been assessed using different breeds in various countries. Several models have been formulated that either handle noncoagulating samples or not. The heritability of MCP is similar to that of other milk quality traits and is higher than the heritability of milk yield. Rennet coagulation time and $\mathrm{a}_{30}$ are highly correlated, both phenotypically and genetically. This means that the use of $\mathrm{a}_{30}$ data does not add valuable information to that obtainable from RCT; both traits are genetically correlated mainly with milk acidity. Moreover, $\mathrm{a}_{30}$ is correlated with casein content. The major limitations of traditional MCP can be overcome by prolonging the observation period and by using a novel $\mathrm{CF}_{\mathrm{t}}$ modeling, which uses all available information provided by computerized renneting meters and allows the estimation of RCT, the potential asymptotic curd firmness, the curd-firming rate, and the syneresis
\end{abstract}

Received March 5, 2012.

Accepted August 5, 2012.

${ }^{1}$ Corresponding author: mauro.penasa@unipd.it rate. Direct measurements of RCT obtained from both mechanical and optical devices show similar heritabilities and exhibit high phenotypic and genetic correlations. Moreover, mid-infrared reflectance spectroscopy can predict MCP. The heritabilities of predicted MCP are higher than those of measured MCP, and the 2 sets of values are strongly correlated. Therefore, midinfrared reflectance spectroscopy is a reliable and cheap method whereby MCP can be improved at the population level; this is because such spectra are already routinely acquired from the milk of cows enrolled in milk recording schemes.

Key words: milk coagulation time and curd firmness, syneresis, genetic parameter, mid-infrared spectroscopy

\section{INTRODUCTION}

\section{Milk Coagulation Properties Are Relevant in the Dairy Industry}

Cheese making requires milk coagulation and development of syneresis. Milk coagulation properties (MCP) have received a great deal of attention from the dairy industry, principally because the amount of milk used for cheese production is growing worldwide (International Dairy Federation, 2011). In the last decade, the fraction of total milk destined to cheese production has increased by about $10 \%$ in the European Union and North America, and it is now slightly higher than 50\% in the former continent and slightly lower in the latter. An increase in the amount of milk used to manufacture cheese has been reported in other European countries, Oceania, and Latin America, and the amount used is much lower in Asia and Africa.

Several studies have confirmed that analysis of MCP yields information relevant for cheese processing, yield, and quality at the laboratory level (Ng-Kwai-Hang et al., 1989; Riddell-Lawrence and Hicks, 1989; Walsh et al., 1998; Wedholm et al., 2006; Alipanah and Kalashnikova, 2007) and industrial level (Bynum and Olson, 1982b; Grandison et al., 1985; Aleandri et al., 1989; Ikonen et al., 1999b; Buchberger and Dovč, 2000; Johnson et al., 2001; Summer et al., 2003; De Marchi et al., 2008). In addition, MCP influence the sensory 
properties of cheese (Martin et al., 1997). Milk coagulation properties are of particular importance in the preparation of Protected Designation of Origin (PDO) cheeses (Mariani and Battistotti, 1999; Bertoni et al., 2005; Bittante et al., 2011a). Such cheeses are produced using traditional processing methods, and cheese quality relies on MCP. In some instances, the MCP of herd bulk milk used to produce PDO cheeses are periodically analyzed and the data used to reward or penalize producers (Calamari et al., 2005; Bittante et al., 2011b).

The objective of this review paper is to provide an insight into the genetic aspects of MCP by considering the effects of species, breed, major genes, and polygenes. The limitations of current MCP testing will also be reviewed. The need to develop new models of milk coagulation, curd firming, and syneresis will be emphasized.

\section{MCP Are Measured with Various Instruments and Yield Different Traits}

The most common approach toward analysis of $\mathrm{MCP}$, at both the research and industry levels, is lactodynamography. This technique monitors the viscosity of milk samples, maintained at a fixed temperature, following addition of rennet. Several approaches can be used to determine MCP (Bynum and Olson, 1982a; O'Callaghan et al., 2002; Kübarsepp et al., 2005; Fagan et al., 2007a,b; Klandar et al., 2007). Although dynamic rheometry is often used in research laboratories (Glantz et al., 2010; Frederiksen et al., 2011; Jakob et al., 2011), the Formagraph (from the Italian word formaggio, for cheese; Foss Electric A/S, Hillerød, Denmark) has been customized to permit simultaneous evaluation of several milk samples and has been widely used for decades (Annibaldi et al., 1977; Zannoni and Annibaldi, 1981; McMahon and Brown, 1982; Okigbo et al., 1985a,b,c). Formagraph-based MCP measurement involves analysis of the behavior of small-loop pendula immersed in linearly oscillating samples of coagulating milk. Minute forces are applied to the pendula because of gel formation in the moving milk (McMahon and Brown, 1982). These forces are recorded and produce a typical Formagraph output, as shown in Figure 1 (McMahon and Brown, 1982). In the earlier versions of the instrument, each output was graphed on photographic paper and all measurements were performed manually. Three singlepoint parameters are considered to be useful MCP: (1) rennet coagulation time (RCT, min), obtained by measuring the interval from time zero (the moment of addition of rennet to milk) to the time at which the baseline begins to widen; (2) the time to a curd firmness $(\mathbf{C F})$ of $20 \mathrm{~mm}\left(\mathbf{k}_{\mathbf{2 0}}, \mathbf{m i n}\right)$, which is the interval from the start of gel formation (RCT) to the time at

\section{ENZYME ADDITION}

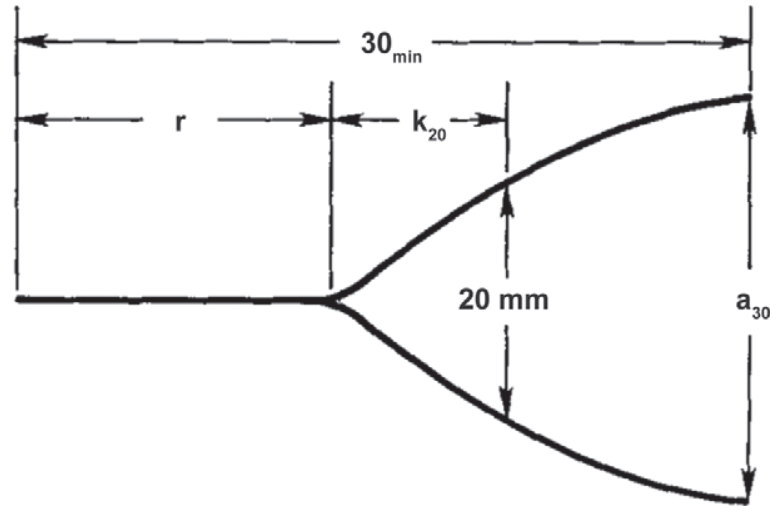

Figure 1. Diagram of rennet coagulation time $(\mathrm{r}=\mathrm{RCT}$, min) and curd firmness traits [time to curd firmness of $20 \mathrm{~mm}\left(\mathrm{k}_{20}, \mathrm{~min}\right)$, and curd firmness 30 min after enzyme addition $\left.\left(\mathrm{a}_{30}, \mathrm{~mm}\right)\right]$ as a function of time (lactodynamographic curve) as recorded with the original Formagraph (Foss Electric A/S, Hillerød, Denmark). Reproduced with permission from McMahon and Brown (1982).

which the oscillation width becomes $20 \mathrm{~mm}$; and (3) the CF 30 min after enzyme addition $\left(\mathbf{a}_{\mathbf{3 0}}, \mathbf{m m}\right)$, which corresponds to the width of the graph $30 \mathrm{~min}$ after rennet addition.

Since the earliest studies of MCP, different shapes of lactodynamographic curve have been recognized (Figure 2; Annibaldi et al., 1977). Combinations of the $3 \mathrm{MCP}$ have been used to classify milk as optimal, suboptimal, defective, and noncoagulating (NC; Table 1). Compared to the optimal curve (type A), type B is a late-coagulating milk with normal curd firming and is frequent in late lactation; type $\mathrm{C}$, in contrast, is an early-coagulating milk with slow curd firming and is more frequent at the beginning of lactation; type $\mathrm{D}$ is an early-coagulating milk with fast and intense curd firming and is typical of milks very rich in casein or slightly acid milks; type $\mathrm{E}$ is a late-coagulating milk with very slow curd firming, denoting a low reactivity to rennet and is frequent in cows with secretion disorders and high SCC and in cows with some genetic variants of $\kappa$-casein; type $\mathrm{F}$ is a more-extreme variant of type E, with only a very late beginning of some coagulation, frequent in high-pH milk from cows with clinical mastitis; type DD, in contrast, is a very early coagulating milk with a rapid and strong $\mathrm{a}_{30}$, frequent in very acid milks; and last, type FF is an NC milk (Annibaldi et al., 1977). It is evident that MCP are characterized by intermediate optimum values and by equilibrium among them. The defects of late or no coagulation and slow curd firming are more severe and frequent than the opposite defects.

Currently, the lactodynamograph performs all measurements automatically, continuously stores the raw 

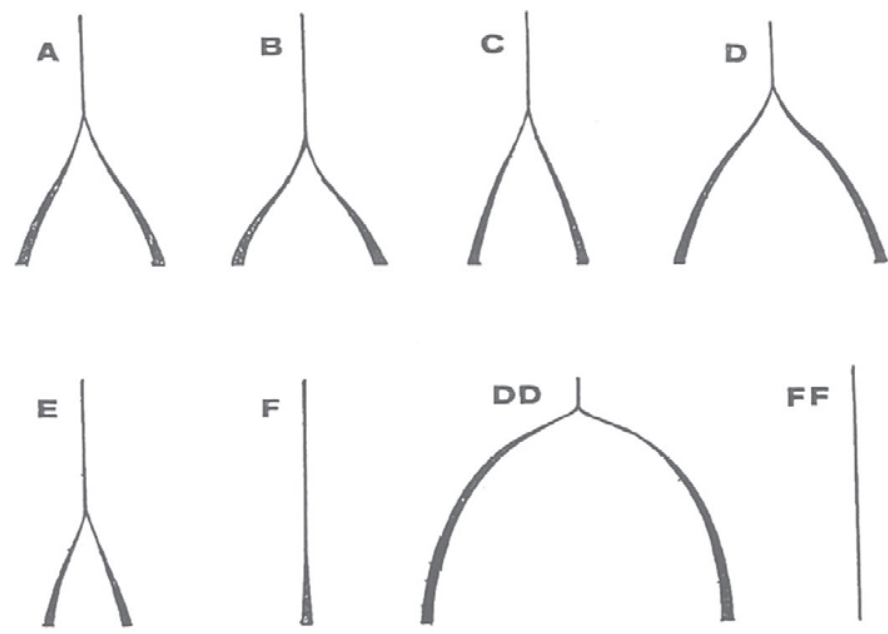

$\mathbf{F F}$

Figure 2. Classification of the most common lactodynamographic curve shapes, according to Annibaldi et al. (1977; used with permission).

data in computer memory (Figure 3), and analyzes the data to yield the traditional MCP outputs and the lactodynamographic curve.

The 3 common MCP are characterized by high variability. Sources of variation are 4-fold: (1) instrument type and setup (operating temperature, the amount and form of enzyme added to milk); (2) repeatability and reproducibility of the technique; (3) pretreatment of milk samples (including the time interval since sampling, the use of preservatives, storage conditions, preheating, addition of starter, $\mathrm{pH}$ adjustment, and addition of calcium); and (4) milk quality (e.g., chemical composition, physical properties, microbiome, contaminants), which is generally the target of MCP analysis. Sources of variation can be further divided in 2 subcategories; namely, genetic (species, breed, major

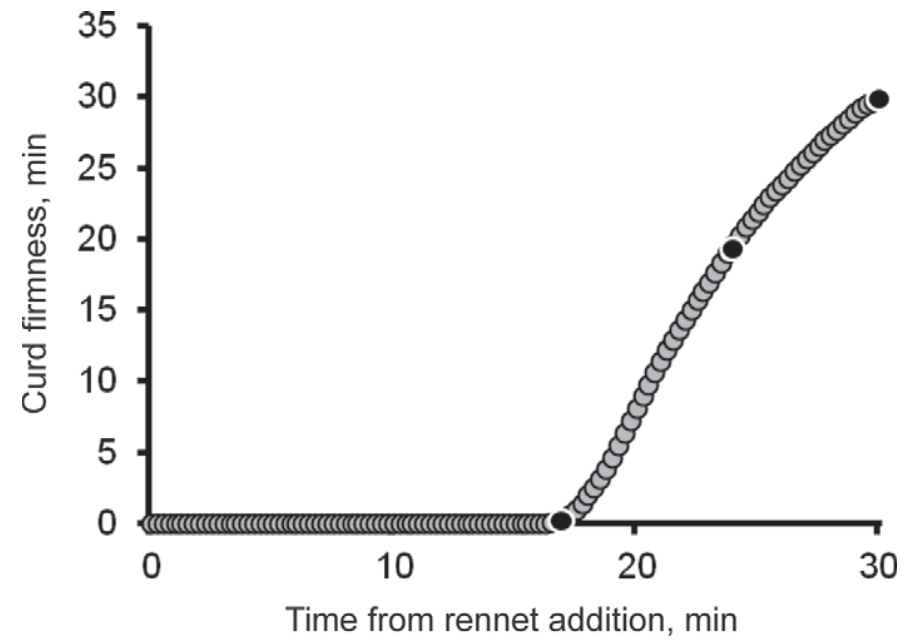

Figure 3. Plot of individual curd firmness data registered by a computerized renneting meter (Formagraph, Foss Electric A/S, Hillerød, Denmark) during $30 \mathrm{~min}$ after rennet addition (one value registered every $15 \mathrm{~s}=120$ observations) and of the 3 values used for traditional computation of rennet coagulation time (RCT), time to curd firmness of $20 \mathrm{~mm}\left(\mathrm{k}_{20}\right)$, and curd firmness $30 \mathrm{~min}$ after enzyme addition $\left(\mathrm{a}_{30}\right)$.

genes, polygenes) and environmental. Environmental conditions (e.g., climate, season, farming systems, feeding, hygiene, health, milking conditions) are important factors affecting MCP. Although environmental factors are not the subject of the present paper, the proportion of variation of MCP explained by environmental factors will be briefly discussed.

\section{FACTORS AFFECTING MCP}

\section{Ruminant Species Vary Greatly In MCP}

Milk composition and properties differ greatly among different ruminant species. Recent reviews on this

Table 1. Classification of milk according to the shape of lactodynamographic curves and their desirability for the dairy industry (Annibaldi et al., 1977)

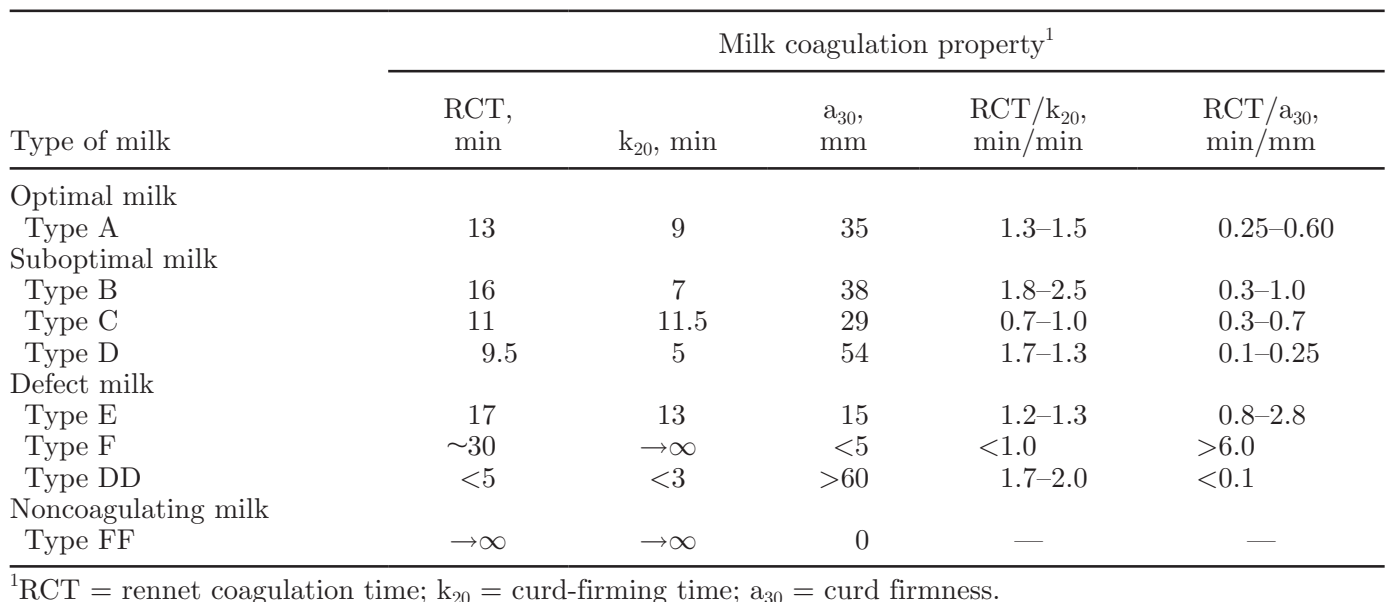


subject have not addressed differences regarding MCP (Vera et al., 2009; Barłowska et al., 2011; Medhammar et al., 2012). Lactodynamographic techniques were initially established to evaluate bovine milk, which constitutes about $80 \%$ of commercially produced milk worldwide. Renneting meters have been widely used to study the milk of other ruminants, but instrument setup and environmental conditions differ among studies. Thus, direct comparisons of the data from earlier reports are not feasible.

Figure 4 shows data obtained upon analysis of cow, sheep, and goat milks, using the same instrument and identical experimental conditions for $90 \mathrm{~min}$, a much longer observation period than typical (G. Bittante, unpublished data). Figure 4 shows that traditional MCP obtained using a lactodynamograph optimized to analyze bovine milk samples may not be particularly valuable when used to explore the curd-firming process of milk from other species. It is worth noting that milk from small ruminants coagulates earlier than cow milk and thus the time interval between enzyme addition and the attainment of $\mathrm{a}_{30}>1 \mathrm{~mm}$ is shorter in small ruminants, in agreement with data from Park et al. (2007). In addition, the $\mathrm{k}_{20}$ value is much shorter for the milk of small ruminants than for cow milk. However, in sheep milk, a CF of $20 \mathrm{~mm}$ represents less than half of the maximum $\mathrm{CF}$, and $\mathrm{k}_{20}$ is thus measured over an interval in which the firming speed is increasing. In cow milk, and even more so in goat milk, a $\mathrm{CF}$ of $20 \mathrm{~mm}$ is closer to the maximum CF attainable (thus, $\mathrm{k}_{20}$ is measured over an interval during which the firming speed is falling). In all species, CF increases to a maximum and then progressively decreases. This phenomenon is attributable to syneresis (Calvo and Balcones, 2000), which causes expulsion of whey from curd, even in the absence of curd cutting. This is because the vessels used for MCP analysis are small in volume $(10 \mathrm{~mL})$. The most obvious difference among species is that syneresis usually takes place much earlier in the milk of small ruminants than in the milk of cows; maximum $\mathrm{CF}$ values are attained within $30 \mathrm{~min}$ from rennet addition in the former and after $30 \mathrm{~min}$ when cow milk is processed. Consequently, $\mathrm{a}_{30}$ values are usually measured in the ascending phase of the CF curve when bovine milk is analyzed, but in the descending phase when milk from small ruminants is tested. The traditional lactodynamograph setup for analysis of bovine milk was designed to explore primarily the coagulation and the curd-firming process, not syneresis. However, the effects of these phenomena overlap in the case of milk samples from sheep and goats. Moreover, the milk of cows and ewes reacts differently to acidification, temperature changes, calcium addition, and variation in rennet concentration (Bencini, 2002).

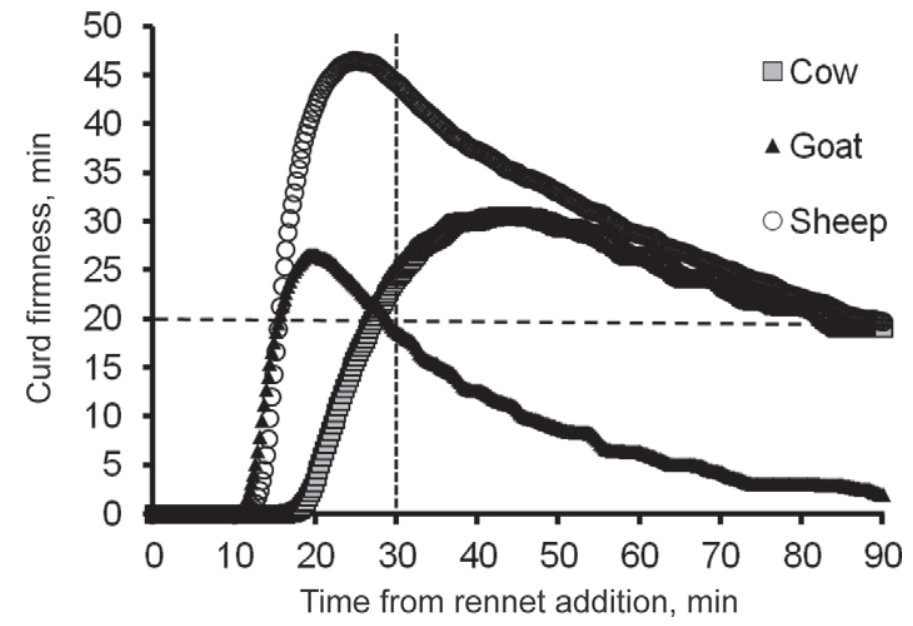

Figure 4. Curd firmness registered for $90 \mathrm{~min}$ after rennet addition to milk produced from Holstein-Friesian cows, Saanen goats, and Massese sheep (G. Bittante, unpublished data).

If analyzed using the same instrument and under the same experimental conditions (Cecchinato et al., 2012a), buffalo milk coagulates earlier and attains a higher $\mathrm{a}_{30}$ value than bovine milk, but shows similar syneresis. Traditional MCP are of greater importance for the buffalo cheese industry (Bartocci et al., 2002; Zicarelli, 2004; Ariota et al., 2007; Potena et al., 2007a,b; Bartocci and Terramoccia, 2010) than for the goat and sheep cheese industries because of the confounding effects of curd firmness and syneresis on the $\mathrm{a}_{30}$ trait.

Comparisons of data derived from the milk of different species confirm that CF modeling requires reevaluation if useful information is to be obtained. This fact will be emphasized in the Modeling of Curd Firming and Syneresis section of the present review.

\section{Breed Strongly Affects MCP}

The second most important genetic feature influencing MCP is breed within species. Differences in MCP among breeds have been studied for many years, beginning immediately after introduction of lactodynamographic techniques. Several reports on this topic have appeared but the work has been often performed under very different experimental conditions. Thus, environmental conditions, feeding regimen, number of sampled animals, number of samples analyzed for each animal, use or not of preservative, time interval between sampling and MCP measurement, milk storage conditions, milk pretreatment (warming, acidification, or starter culture addition), type of instrument used, type and quantity of rennet used, temperature of coagulation, duration of observation, traits recorded, consideration afforded to NC samples, statistical methods employed, 
Table 2. Summary of results of comparison of milk coagulation properties of cows of different breeds ${ }^{1}$

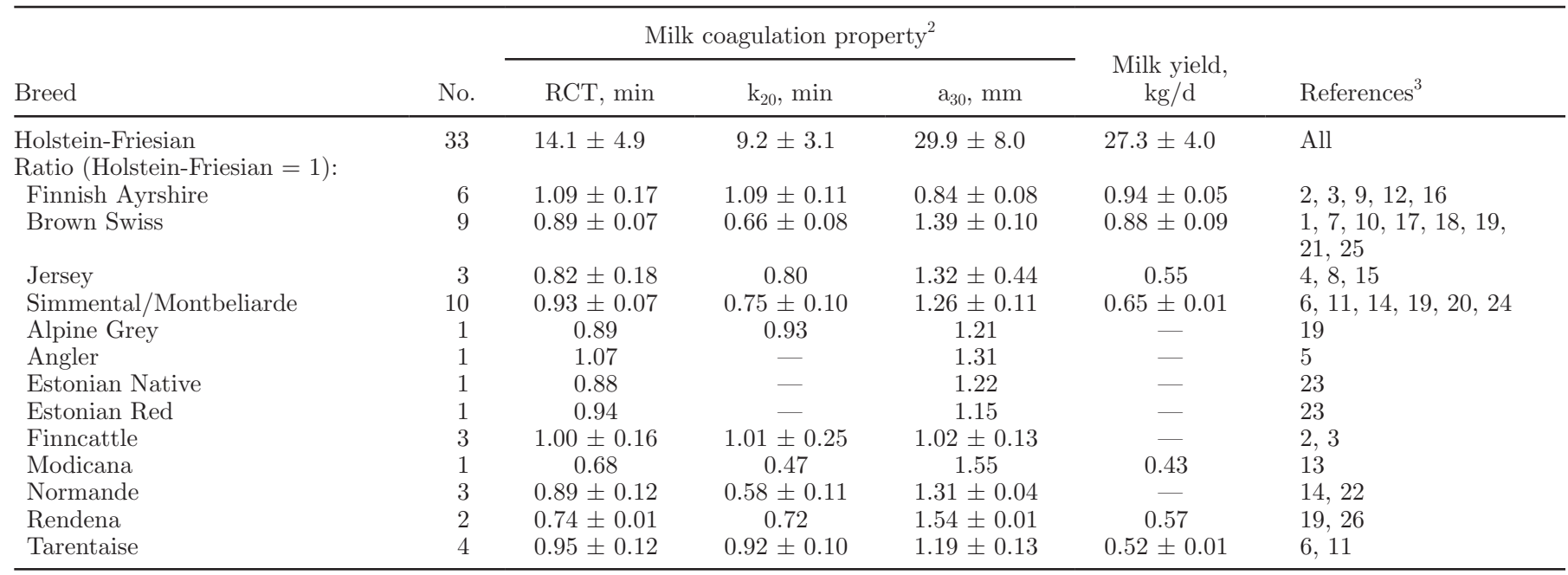

${ }^{1}$ To reduce the effect of different conditions and methodologies, only trials comparing Holstein-Friesian cows with cows of other breeds were considered, and the average values of other breeds are expressed as a ratio respect to the average value of Holstein-Friesian.

${ }^{2} \mathrm{RCT}=$ rennet coagulation time; $\mathrm{k}_{20}=$ curd-firming time; $\mathrm{a}_{30}=$ curd firmness.

${ }^{3} 1=$ Mariani et al. (1984); $2=$ Tervala et al. (1985; $\mathrm{a}_{10}$ instead of $\left.\mathrm{a}_{30}\right) ; 3=$ Aaltonen and Antila (1987); $4=$ Bastian et al. (1991); $5=$ Oloffs et al. (1992); $6=$ Macheboeuf et al. (1993a); $7=$ Malossini et al. (1996); $8=$ Kreuzer et al. (1996); $9=$ Ikonen et al. (1997); 10 = Mariani et al (1997); 11 = Verdier-Metz et al. (1998); $12=$ Ikonen et al. (1999a); $13=$ Chiofalo et al. (2000); $14=$ Auldist et al. (2002); $15=$ Auldist et al. (2004); 16 = Tyrisevä et al. (2004); $17=$ Malacarne et al. (2005); $18=$ Malacarne et al. (2006); $19=$ De Marchi et al. (2007); 20 = Pomiès et al. (2007); $21=$ De Marchi et al. (2008); $22=$ Hurtaud et al. (2009); $23=$ Jõudu et al. (2009); $24=$ Martin et al. (2009); $25=$ Cecchinato et al. (2011a); 26 = Mantovani et al. (2011).

and manner in which results were presented varied greatly among the reports. The effects of the variables mentioned above will be discussed in the sections that deal with estimation of heritability estimates for MCP. Because the experimental conditions are so variable, direct comparisons among breeds can be made only using data obtained within a single trial. To extract useful information on among-breed variation from the various reports, we adopted the following procedure: (1) reports (or individual experimental trials) conducted under extreme or unusual conditions or that calculated MCP in an unconventional manner were not considered; (2) because almost all reports included data on milk from the Holstein-Friesian, this breed was adopted as a reference; (3) because both the extent of variability and the observed among-breed differences were often proportional to the average MCP values derived in a particular report, the average MCP of any given breed was expressed as a ratio of the MCP of that breed to the same MCP of the Holstein-Friesian (assumed to be 1.00); and (4) the ratios thus obtained were used to calculate means and standard deviations for each breed.

The comparison of MCP from different cattle breeds are summarized in Table 2 . The mean values of 33 estimates from Holstein-Friesians were $14.1 \mathrm{~min}$ for RCT, $9.2 \mathrm{~min}$ for $\mathrm{k}_{20}$, and $29.9 \mathrm{~mm}$ for $\mathrm{a}_{30}$, with a tendency toward an elongation of RCT and a delay in the time needed to attain a $\mathrm{CF}$ of $20 \mathrm{~mm}$ in recent years. The variations are large; the coefficients of variation $(\mathbf{C V})$ were 35,34 , and $27 \%$ for $\mathrm{RCT}, \mathrm{k}_{20}$, and $\mathrm{a}_{30}$, respectively. It should be noted that only 23 estimates of $k_{20}$ have been reported; this is because the proportion of samples that failed to attain a CF of $20 \mathrm{~mm}$ within $30 \mathrm{~min}$ after rennet addition is often high. The average milk yield of Holstein-Friesian cows was $27.3 \pm 4.0 \mathrm{~kg} / \mathrm{d}$. The breeds most commonly analyzed and compared with HolsteinFriesians were the Ayrshire, Brown Swiss, Jersey, and Simmental/Montbeliarde.

Milk from Ayrshire cows is characterized by slightly longer RCT, longer $\mathrm{k}_{20}$, and lower $\mathrm{a}_{30}$ compared with that from Holstein-Friesians. However, the variabilities of the ratios calculated were high; indeed, for RCT, 1 value smaller than that of Holstein-Friesian has been reported.

Brown Swiss cows yielded very favorable MCP; milk from this breed shows shorter $\mathrm{k}_{20}$ and higher $\mathrm{a}_{30}$ compared with milk from Holstein-Friesian. In addition, the variability of MCP data was much lower than were the average differences calculated with respect to the reference Holstein-Friesian breed.

All 3 MCP values derived using milk from Jerseys were very variable, although the average values were favorable, suggesting that further work is required. On average, the milk of Simmental and Montbeliarde cows 
showed better MCP than milk of Holstein-Friesians but not as good as those of Brown Swiss.

Several reports calculated MCP of local breeds, but the number of estimates per breed was low (1 to 4). With the exception of MCP of Finncattle and the RCT of the Angler breed, which were similar to those of Holstein-Friesians, local breeds generally showed more favorable MCP than did the cosmopolitan reference breed. In particular, Italian Rendena and Modicana breeds produce milk of a quality that is even more favorable than that of Brown Swiss cows. Although other among-breed comparisons have been made, the data are not included in Table 2 because the MCP were calculated using different methods (Wedholm et al., 2006; Barłowska et al., 2009; Glantz et al., 2009).

In general, the milk of breeds that originated in central-southern Europe, and especially the Alpine region, is characterized by shorter $\mathrm{RCT}$, faster $\mathrm{k}_{20}$, and higher $\mathrm{a}_{30}$ than milk of breeds that originated in centralnorthern Europe. Although MCP from crossbred cows have been studied by some authors (Kreuzer et al., 1996; Tyrisevä et al., 2004), no estimates of heterosis are available. Only a few reports have compared MCP derived from the milk of different breeds of sheep and goats so that no general conclusions can be drawn.

\section{Milk Proteins and Their Genetic Variants Strongly Affect MCP}

The third genetic influence on MCP is the structure of genes encoding major milk proteins, and particularly the effects of their genetic variants. The 6 principal milk proteins of cattle are encoded by highly polymorphic genes, with up to 47 variants identified. The significance of such polymorphism in terms of both animal breeding and human nutrition has recently been reviewed by Caroli et al. (2009). Work on the effects of milk protein genetic variants on $\mathrm{MCP}$ commenced decades ago and an impressive volume of data has been collected, as reviewed by Jakob and Puhan (1992).

The effects of genetic variants of milk proteins on MCP have been studied under very different conditions. In addition, the statistical models used to estimate the effects of genetic variants have not been uniform in nature. To reduce the effects of environmental and statistical variation, the first homozygous genotype of each locus was chosen as a reference (and was thus assigned a value of 1.00 to its MCP estimate); the estimates of other genotypes at the same locus are expressed as ratios to the reference. The ratios obtained in different studies were then averaged and the standard deviations calculated (Table 3 ).
Sixteen reports (24 experiments) compared data from at least 2 genotypes at an individual locus. The CV of MCP were very high, being 38,43 , and 26 for RCT, $\mathrm{k}_{20}$, and $\mathrm{a}_{30}$, respectively. The reports contain data on the milk of several breeds.

The most widely studied locus was CSN3 (encoding $\kappa$-casein; 24 estimates). Cows with the heterozygous AB genotype yielded more favorable MCP than did animals with the AA genotype. On average, reductions of 9 and $30 \%$ in RCT and $\mathrm{k}_{20}$, respectively, and an increase of $26 \%$ in $\mathrm{a}_{30}$ were noted in heterozygotes. For all MCP, the standard deviations of the $\mathrm{AB}: \mathrm{AA}$ ratios were much lower than were the average differences between $A B$ and AA genotypes. The homozygous $\mathrm{BB}$ genotype has not always been studied in works dealing with the $\kappa$-casein locus. Notably, several studies on HolsteinFriesian cows did not seek to estimate effects of the BB genotype because that genotype occurs at only a low frequency. The average BB:AA ratio strongly suggests that the presence of a $\mathrm{B}$ allele has a very positive effect on MCP. When the ratios yielded by milk samples from heterozygous $\mathrm{AB}$ cows were averaged, the RCT figure was exactly intermediate between those obtained with milk of $\mathrm{AA}$ and $\mathrm{BB}$ cows, but both $\mathrm{k}_{20}$ and $\mathrm{a}_{30}$ were slightly biased toward better values, possibly reflecting a favorable dominance effect.

Some authors have studied milk from heterozygous AE k-casein cows (Table 3); the average estimates on RCT indicate a null effect of the E allele compared with AA cows and an unfavorable effect on $\mathrm{a}_{30}$. In addition, Jõudu et al. (2009) reported that the curd firmness of homozygous EE $\kappa$-casein milk was less satisfactory than that of AA milk, but the RCT of the former milk was better. According to Ojala et al. (2005), the average MCP values of milk from Finnish Ayrshire cows can be improved by selecting against the $\mathrm{E}$ allele of $\kappa$-casein. Lodes et al. (1996a) also estimated the RCT values of milk from $\mathrm{AC}$ and $\mathrm{BC} \kappa$-casein cows; the values did not differ greatly from those of AA animals.

The effects of variants in the gene encoding CSN2 ( $\beta$-casein) have been much less studied than the effects of $C S N 3$ variants, probably because variations in genotype at this locus yield only minor and often controversial effects (Table 3 ). Only the B allele of $\beta$-casein seems to have a favorable effect on the RCT of milk from heterozygous cows, as confirmed by Lodes et al. (1996a), who studied homozygous BB cows.

The effects of variants in the gene encoding CSN1 $\left(\alpha_{S 1}\right.$-casein $)$ have been little studied because of the small number of minor alleles and small effect on MCP (Jõudu et al., 2007).

The CSN1, CSN2, and CSN3 genes are encoded on chromosome 6; hence, recombination among alleles is 
Table 3. Summary of results of comparison of milk coagulation properties ${ }^{1}$ of cows of different genotypes for milk protein variants ${ }^{2}$

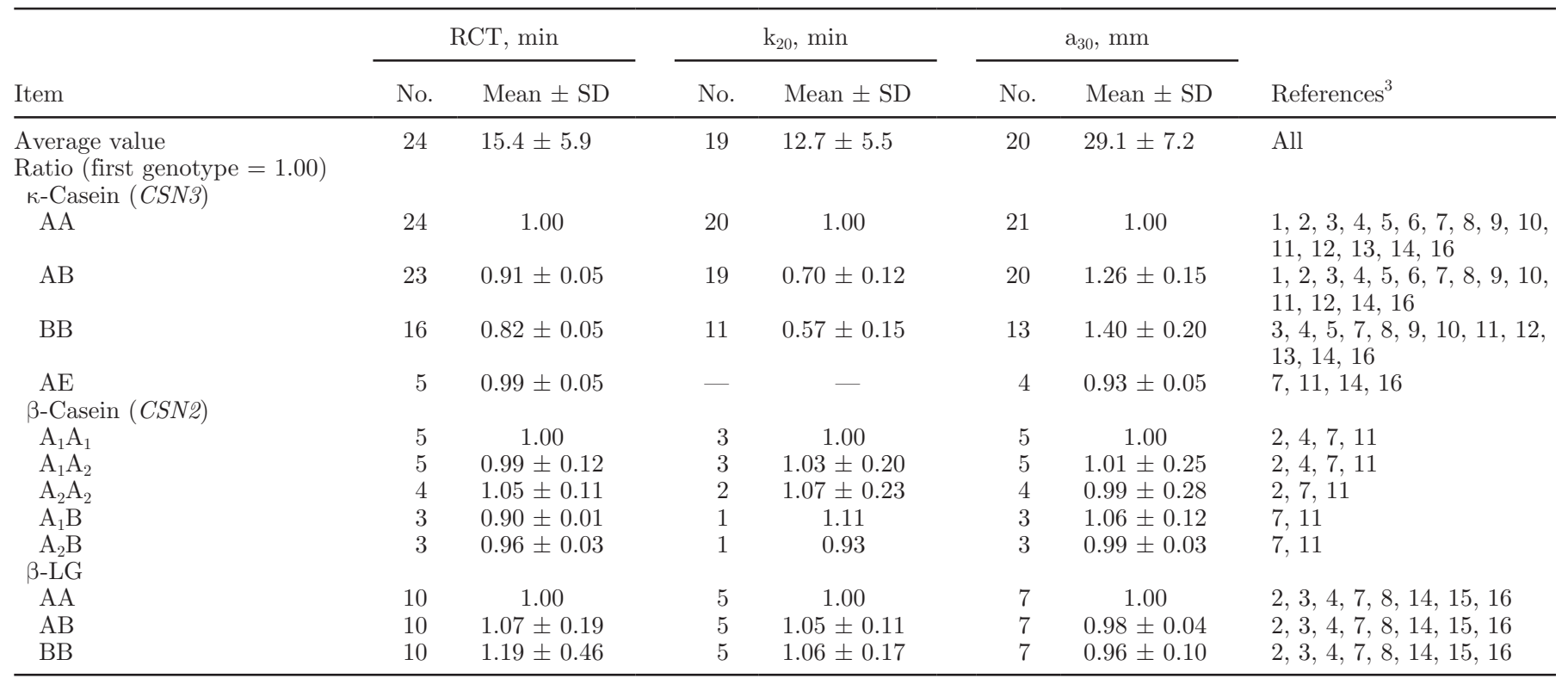

${ }^{1} \mathrm{RCT}=$ rennet coagulation time; $\mathrm{k}_{20}=$ curd-firming time; $\mathrm{a}_{30}=$ curd firmness.

${ }^{2}$ To reduce the effect of different conditions and methodologies, for each locus, the average values of genotypes were expressed as a ratio respect to the average value of the first.

${ }^{3} 1=$ Schaar (1984); $2=$ Tervala et al. (1985); $3=$ Aaltonen and Antila (1987); 4 = Marziali and Ng-Kwai-Hang (1986); $5=$ Pagnacco and Caroli (1987); 6 = Davoli et al. (1990); $7=$ Oloffs et al. (1992); 8 = van den Berg et al. (1992); 9 = Macheboeuf et al. (1993a); $10=$ Macheboeuf et al. (1993b); 11 = Lodes et al. (1996a); $12=$ Mariani et al. (1997); $13=$ Saccà et al. (2003); $14=$ Kübarsepp et al. (2006); $15=$ Jõudu et al. (2007); 16 = Jõudu et al. (2009).

limited. However, some reports have explored MCP in animals using a $\beta$-к-casein (CSN2/CSN3) composite genotype or haplotype (Mayer et al., 1997; Amigo et al., 2001; Comin et al., 2005, 2008; Hallen et al., 2007). Because many different combinations are possible, the results of these studies cannot be easily summarized, but the data generally confirm those listed in Table 3 .

Although whey proteins are not involved in gelation, data from 10 studies (Table 3) reveal a moderate effect of $\beta$-LG genotype on MCP. In particular, the average $\mathrm{MCP}$ values of the BB genotype were somewhat poorer than those of the AA genotype, and the MCP of heterozygous $\mathrm{AB}$ genotype were intermediate. However, the variability of estimation is very large and any effect of this gene needs to be studied further. Moreover, Oloffs et al. (1992) found that the BC $\beta$-LG genotype negatively affected both RCT and $\mathrm{a}_{30}$.

Jensen et al. (2012) used a proteomics approach consisting of 2-dimensional gel electrophoresis coupled to mass spectrometry on milk samples characterized by extreme MCP and observed prevalence of the $\mathrm{B}$ variants of $\beta-\mathrm{CN}, \kappa-\mathrm{CN}$, and $\beta-\mathrm{LG}$ in milk with good MCP. Moreover, the authors found that phosphorylation and glycosylation of $\kappa-\mathrm{CN}$ were not associated with breed of cow or MCP of milk.
The way in which variation in milk protein traits affects the genetics of MCP involves effects of genotype on crude protein content, the levels and proportions of individual protein fractions, milk acidity, and mineral content (Figure 5). As described in several reports, genetic variants of milk proteins influence both the amount and proportion of different proteins in milk (Ng-Kwai-Hang et al., 1987; Lodes et al., 1996b; Ikonen et al., 1999c, 2001; Buchberger and Dovč, 2000; Boettcher et al., 2004; Barber et al., 2005). In addition, the dimensions of casein micelles are influenced by genetic variants (McMahon and Brown, 1984; Lodes et al., 1996b).

Moreover, the amount of some protein fractions has been shown to influence MCP (Marziali and Ng-KwaiHang, 1986; Politis and Ng-Kwai-Hang, 1988; Auldist et al., 2004; Jõudu et al., 2008). In genetic terms, an increase in either total $\kappa$-casein content or relative proportion of $\kappa$-casein with respect to total casein levels, decreases in overall levels or relative proportions of milk $\alpha_{\mathrm{S} 1^{-}}$and $\alpha_{\mathrm{S} 2^{-}}$caseins, and $\mathrm{pH}$ exert favorable effects on MCP. Any effect of $\beta$-casein on MCP remains controversial (Auldist et al., 2004; Wedholm et al., 2006; Jõudu et al., 2008, 2009; Bonfatti et al., 2011). Certain variations in milk characteristics can be attributed to 


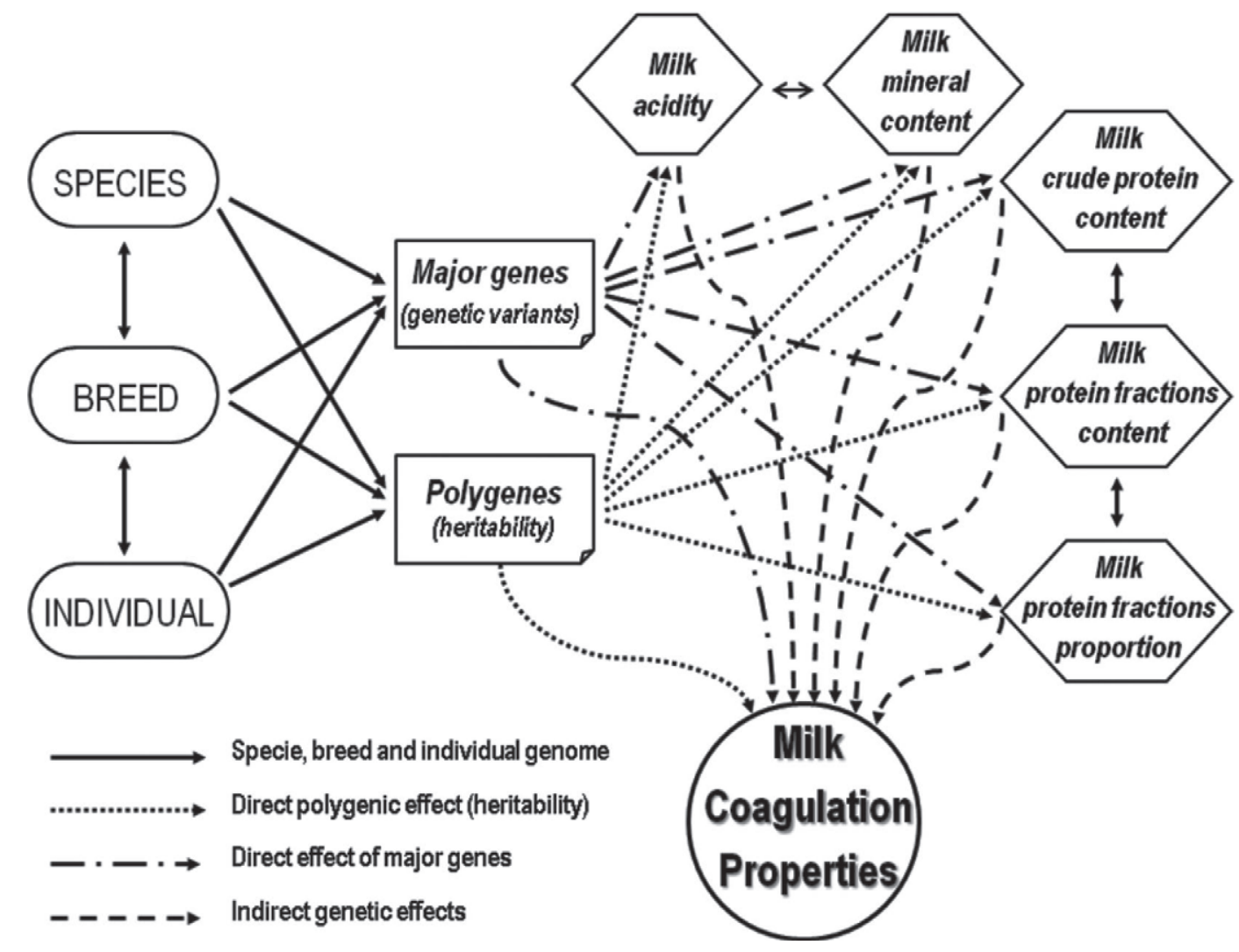

Figure 5. Direct and indirect genetic effects on milk coagulation properties.

qualitative (i.e., structural) differences between allelic products of milk protein genes or quantitative differences (i.e., the amount of such proteins). Therefore, some reports have sought to estimate the extent to which the effect of genetic variants on MCP can be explained via an effect on the levels of particular protein fractions in milk, and to what degree such variation is independent of these effects (Aaltonen and Antila, 1987; Ikonen et al., 1997; Heck et al., 2009; Bonfatti et al., 2010).

\section{Among-Breed Differences in MCP and Milk Protein Genotypes}

Different breeds are characterized by variation in the frequencies of the possible allelic forms of milk proteins. Certain questions arise: What is the relative importance of breed or milk protein genotype on MCP? What relationships exist among these parameters? Ikonen et al. (1999a), comparing the MCP of Finnish Ayrshire and Finnish Friesian cows, found that the difference attributable to breed was reduced by $38 \%$ for RCT and by $20 \%$ for $\mathrm{a}_{30}$ after correcting the breed effects for $\beta$ - $\kappa$ casein and $\beta$-LG genotypes (Table 4). Using a similar approach but adjusting only for the effect of $\kappa$-casein,
Auldist et al. (2002) found that differences between the MCP of Irish Friesian, US Holstein-Friesian, Montbeliarde, and Normande cows were reduced by 20 to $35 \%$ for RCT, 41 to $58 \%$ for $\mathrm{k}_{20}$, and 0 to $31 \%$ for $\mathrm{a}_{60}$ (Table 4). It is thus obvious that the extent of any difference between the MCP of any 2 breeds that is attributable to variation in milk protein genotype is a function of the difference in allele frequencies between those breeds, in particular those of the $\kappa$-casein genotype. We conclude that differences among loci controlling the relative proportions of milk proteins contribute significantly to the differences in MCP exhibited by cows of different breeds. It remains true, however, that many other genetic factors (polymorphisms in other major genes, polygene expression, gene interactions, and inbreeding level) contribute to the cheese-making attributes of milk from cows of various breeds.

The effects of genetic variants of milk protein content on MCP seem to be explained, at least in part, by the effects of genetic variation on the amount and proportion of different milk proteins. These proteins vary in terms of level and proportion among different breeds. Further obvious, but as yet unanswered, questions arise: What is the relative importance in different 
Table 4. Estimates of differences in milk coagulation properties ${ }^{1}$ between different breeds obtained with statistical models unadjusting or adjusting for the effect of milk genetic variants

\begin{tabular}{|c|c|c|c|c|c|c|}
\hline Study/parameter ${ }^{2}$ & \multicolumn{2}{|c|}{$\mathrm{RCT}, \min$} & \multicolumn{2}{|c|}{$\mathrm{k}_{20}, \min$} & \multicolumn{2}{|c|}{$\mathrm{a}_{30-60}, \mathrm{~mm}$} \\
\hline \multicolumn{7}{|l|}{ Ikonen et al. (1999a) } \\
\hline $\mathrm{FA}-\mathrm{FF}$ & +3.2 & +2.0 & - & - & -9.8 & -7.8 \\
\hline$P$-value ${ }^{3}$ & $<0.01$ & 0.02 & - & - & $<0.01$ & $<0.01$ \\
\hline \multicolumn{7}{|l|}{ Auldist et al. (2002) } \\
\hline $\mathrm{HF}-\mathrm{IF}$ & -1.0 & -0.8 & -1.7 & -1.0 & +3 & +3 \\
\hline$P$-value ${ }^{4}$ & $<0.01$ & NS & $<0.01$ & NS & $<0.01$ & NS \\
\hline
\end{tabular}

${ }^{1} \mathrm{RCT}=$ rennet coagulation time; $\mathrm{k}_{20}=$ curd-firming time; $\mathrm{a}_{30}=$ curd firmness.

${ }^{2} \mathrm{FA}-\mathrm{FF}=$ difference between the estimates of the Finnish Ayrshire and the Finnish Friesian cows; HF - IF = difference between the estimates of the Holstein-Friesian and the Irish Friesian cows; MO - IF = difference between the estimates of the Montbeliarde and the Irish Friesian cows; $\mathrm{NO}-\mathrm{IF}=$ difference between the estimates of the Normande and the Irish Friesian cows.

${ }^{3} \beta-\kappa$-Casein and $\beta$-LG genotypes in the model, $a_{30}$.

${ }^{4} \kappa$-Casein genotypes in the model, $\mathrm{a}_{60}$.

breeds? What relationships exist among the level and the proportion of a particular protein in terms of $\mathrm{MCP}$ in different breeds?

\section{Major Genes Other than Milk Protein Genes Affect MCP}

Many QTL studies have been performed to identify genetic traits important in terms of milk production (for a review, see Ogorevc et al., 2009). These studies have used marker-assisted selection, but the outcomes have, to date, yielded traits that can be measured only in large-scale trials (Georges et al., 1995; Komisarek and Dorynek, 2006; Schennink et al., 2007; Banos et al., 2008; Ibeagha-Awemu et al., 2008). This is because such work requires examination of large numbers of cows and no cost-effective method permitting analysis of milk from large number of individual animals is available.

Genes other than those encoding milk proteins may also serve as useful markers for desirable cheese characteristics. Recently, Tyrisevä et al. (2008), in a study on Finnish Ayrshire cows, conducted large-scale scanning (using a selective DNA pooling method) to identify genomic regions associated with $\mathrm{NC}$ milk. A daughter design and selective genotyping within families were employed for this purpose. The results showed that BMS1126 on chromosome 2 and BMS1355 on chromosome 18 were associated with noncoagulation of milk across the families. The authors identified 2 potential noncoagulation marker genes; these were LOC538897, located on chromosome 2 and encoding a nonspecific serine/threonine kinase, and SIAT4B on chromosome 18 and encoding a sialyltransferase catalyzing the last step of $\kappa$-casein glycosylation.
Glantz et al. (2011) showed that the genes encoding leptin $(L E P)$ and the leptin receptor $(L E P R)$ encoded proteins of importance in terms of technological cheesemaking features. In particular, the authors showed that the expression of the $\mathrm{T}$ allele of the LEPRT945M polymorphism was associated with higher gel strength, yield stress, and cheese hardness than the $\mathrm{C}$ allele. Moreover, the polymorphism affected milk calcium levels and $\mathrm{pH}$; the authors claimed that expression of the $\mathrm{T}$ allele increased ionic calcium concentrations at both $25^{\circ} \mathrm{C}$ and $32^{\circ} \mathrm{C}$, and reduced milk $\mathrm{pH}$. Other studies have shown that gel strength increases with increasing calcium concentration and reduced milk pH (Glantz et al., 2010). It may be concluded that expression of the LEPRT945M $\mathrm{T}$ allele favors gelation and improves cheese quality. The LEPA252T polymorphism was shown to affect gel strength, and expression of the $\mathrm{T}$ allele improves that strength. The LEPA59V polymorphism affected fat globule size. Hence, it may be possible to control globule size via genetic selection (Glantz et al., 2011).

Among genes affecting MCP, the gene encoding stearoyl-coenzyme A desaturase $1(S C D)$ has been associated with the extent of $\mathrm{a}_{30}$ in Holstein-Friesian cows (Maurmayr et al., 2011; Cecchinato et al., 2012b) and also with protein and casein content and the level of titratable acidity. In the cited studies, presence of the $\mathrm{C}$ allele was generally associated with unfavorable effects on MCP; reductions in both titratable acidity and $\mathrm{a}_{30}$ were clear. The preliminary results of a large trial on the association of 33 candidate genes with MCP of 1,271 Brown Swiss cows (Cecchinato et al., 2012c) confirmed an important role of the $S C D$ gene on RCT, and of LPIN1 (lipin 1), CARD15 (caspase recruitment domain-containing protein 15), and $O R L 1$ (opioid receptor like 1 ) on curd-firming rate and $\mathrm{a}_{30}$. 
Although further work is needed to explore the effects of variation in these genes, the results suggest that variation in allele frequency at several loci exerts some effects on MCP. This means that associations between polymorphisms of these genes and milk traits could be exploited in selection programs. Further advances in knowledge, revealing the potential for exploitation of such variations at the molecular genetics level, may well be achieved via genome-wide association studies and estimations of breeding values using large numbers of phenotyped animals (Glantz et al., 2012). Moreover, promising data have been derived from work on metabolite associations (Bastian et al., 1991; Harzia et al., 2012) and metabolomics (Sundekilde et al., 2011).

\section{Genetic Parameters of MCP Estimated Under Different Conditions and Analytical Procedures}

The fourth genetic topic that we discuss in the present review is the effect of additive polygenic effect on MCP. Since the first estimation of heritability for MCP (Lindström et al., 1984), about 20 reports on genetic parameters have appeared. The analytical conditions of these studies varied greatly and, consequently, the estimates of genetic parameters cannot be easily compared and interpreted.

In most cases, lactodynamographic analyses were performed within $24 \mathrm{~h}$ from sample collection, using refrigerated samples stored without preservative (Table $5)$. Some larger surveys conducted at the population level dealt with samples stored with preservative; these were usually analyzed within some days from collection (Ikonen et al., 1999a, 2004; Tyrisevä et al., 2004; Kaart et al., 2010; Vallas et al., 2010). In some instances, neither sample age nor preservative use was described in the report (Oloffs et al., 1992; Ikonen et al., 1997; Bittante et al., 2002). Dal Zotto et al. (2008) compared results from samples stored with or without preservative and analyzed within $6 \mathrm{~h}$ from collection, and found very high among-sample correlation (0.97) for RCT. However, the correlation was lower $(0.83)$ when $\mathrm{a}_{30}$ was considered. Further, Bittante (2011), comparing results from refrigerated milk samples stored without preservative for up to $5 \mathrm{~d}$ before analysis, found that sample age significantly affected MCP.

With the exception of an early project that used Sommer-Matsen equipment, allowing estimation of only RCT (Lindström et al., 1984), and of some large surveys on Estonian cows performed using an optical instrument (Optigraph, Ysebaert, Frepillon, France), all other studies (Table 5) determined MCP with mechanical equipment (Formagraph, Foss Electric; CRM,
Polo Trade, Monselice, Italy). Differences in the results obtained using mechanical and optical instruments will be discussed later.

The temperature to which samples were heated before enzyme addition was $35^{\circ} \mathrm{C}$ in all cases (Table 5) except in the works of Ikonen et al. (1997, 1999a), who referred to a lower temperature $\left(32^{\circ} \mathrm{C}\right)$, which could have delayed coagulation and curd firming (Kowalchyk and Olson, 1977; Okigbo et al., 1985d; Bencini, 2002; Nájera et al., 2003). No study used a bacterial starter inoculum before enzyme addition.

The duration of the test was very similar among trials: 30 min when the Formagraph was used and 31 min when the CRM (Polo Trade) was used. Only Cecchinato et al. (2011a) prolonged the observation period up to 90 min after enzyme addition, but the authors reported that conventional MCP were measured up to $30 \mathrm{~min}$ from rennet addition.

The major difference among studies in terms of analytical methodology is the type and concentration of enzyme used (Table 5). Thus, data comparison is difficult because the rennet characteristics were often inadequately described. The enzymes were obtained from various suppliers, were used at different concentrations, were provided in either liquid or powder form, and varied in terms of the chymosin:pepsin ratio. Very few studies used international milk-clotting units (IMCU) to quantify the amount of enzyme used.

We sought to calculate IMCU concentrations (Table $5)$. It is clear that the variability among trials is very large; enzyme concentrations ranged from 0.051 (Cecchinato et al., 2011a) to $0.150 \mathrm{IMCU} / \mathrm{mL}$ in the Estonian studies (Kaart et al., 2010; Vallas et al., 2010). Moreover, these last authors did not used rennet but an enzyme of microbial origin. It is known that an increase in the amount of rennet added to milk accelerates both coagulation and curd firming (Okigbo et al., 1985d; Bencini, 2002; Nájera et al., 2003). However, changes in cheese characteristics were also detected, because of the long-term activity of pepsin. The notable effect of enzyme concentration on average MCP is depicted in Figure 6, which plots average RCT values from the studies listed in Table 5 against the estimated IMCU concentrations used.

The effects of variation in sample treatment, and the analytical instruments and methodologies used, combined with differences in the definition of breed and coagulation traits, largely explain the great variability of MCP from several studies (Table 5). Oloffs et al. (1992) did not report average MCP values, Lindström et al. (1984) analyzed only RCT, and Bittante et al. (2002) reported "milk rennet-coagulation ability," which is a combination of RCT and $\mathrm{a}_{30}$ values. 
Table 5. Analytical conditions, incidence of noncoagulating samples (NC) and samples without $\mathrm{k}_{20}$ value (no $\mathrm{k}_{20}$ ), and average milk coagulation properties of coagulating samples obtained in trials aimed at estimating genetic parameters of coagulation properties

\begin{tabular}{|c|c|c|c|c|c|c|c|c|c|c|c|c|}
\hline \multirow[b]{2}{*}{ Reference } & \multirow[b]{2}{*}{$\begin{array}{l}\text { Age of } \\
\text { samples }\end{array}$} & \multirow[b]{2}{*}{ Preservative? } & \multirow[b]{2}{*}{ Instrument $^{1}$} & \multirow[b]{2}{*}{ Temperature } & \multirow[b]{2}{*}{ Rennet $^{2}$} & \multicolumn{7}{|c|}{ Property $^{3}$} \\
\hline & & & & & & $\begin{array}{l}\text { IMCU, } \\
/ \mathrm{mL}\end{array}$ & $\begin{array}{l}\text { Length, } \\
\text { min }\end{array}$ & $\begin{array}{c}\mathrm{NC} \\
\%\end{array}$ & $\begin{array}{c}\mathrm{RCT}, \\
\min \end{array}$ & $\begin{array}{l}\mathrm{No} \mathrm{k}_{20} \\
\%\end{array}$ & $\begin{array}{l}\mathrm{k}_{20} \\
\min \end{array}$ & $\begin{array}{l}\mathrm{a}_{30}, \\
\mathrm{~mm}\end{array}$ \\
\hline Lindström et al. (1984) & $<12 \mathrm{~h}$ & No & Sommer M. & $35^{\circ} \mathrm{C}$ & Hansen St. & - & - & - & 5.3 & - & - & - \\
\hline Tervala et al. (1985) & $1 \mathrm{~d}$ & No & Formagraph & $35^{\circ} \mathrm{C}$ & Hansen St. & - & 30 & 2.1 & 8.5 & 12.9 & 14.9 & $25.4^{4}$ \\
\hline Oloffs et al. (1992) & - & - & Formagraph & - & - & - & - & - & - & 32.0 & - & - \\
\hline Oloffs et al. (1992) & - & - & Formagraph & - & - & - & - & - & - & 19.0 & - & - \\
\hline Ikonen et al. (1997) & - & - & Formagraph & $32^{\circ} \mathrm{C}$ & Renco l. & 0.116 & 30 & 5.2 & 12.4 & 23.0 & 8.1 & 27.2 \\
\hline Ikonen et al. (1997) & - & - & Formagraph & $32^{\circ} \mathrm{C}$ & Renco.l & 0.116 & 30 & 0.0 & 11.3 & 8.4 & 7.4 & 31.2 \\
\hline Ikonen et al. (1999a) & - & Yes & Formagraph & $32^{\circ} \mathrm{C}$ & RCRL & 0.116 & 30 & 7.5 & 12.3 & 32.9 & 9.6 & $25.1^{5}$ \\
\hline Bittante et al. (2002) & - & - & Formagraph & - & - & - & - & 19.0 & $2.36^{6}$ & - & - & - \\
\hline Tyrisevä et al. (2004) & $2 \mathrm{~d}$ & Yes & CRM & $35^{\circ} \mathrm{C}$ & Hansen 190 & 0.114 & 31 & 6.2 & 11.2 & 23.8 & - & $28.8^{5}$ \\
\hline Ikonen et al. (2004) & $<27 \mathrm{~d}$ & Yes & CRM & $35^{\circ} \mathrm{C}$ & Hansen 190 & 0.114 & 31 & 13.3 & 11.8 & 30.0 & - & 27.6 \\
\hline Cassandro et al. (2008) & $3 \mathrm{~h}$ & No & CRM & $35^{\circ} \mathrm{C}$ & Hansen 190 & 0.061 & 31 & 9.7 & 16.9 & - & - & 32.0 \\
\hline Cecchinato et al. (2009) & $3 \mathrm{~h}$ & No & CRM & $35^{\circ} \mathrm{C}$ & Hansen 190 & 0.061 & 31 & 3.5 & 15.0 & - & - & 41.7 \\
\hline Vallas et al. (2010) & $<7 \mathrm{~d}$ & Yes & Optigraph & $35^{\circ} \mathrm{C}$ & Milase 750 & 0.150 & 31 & 0.3 & $10.0^{7}$ & - & - & 27.0 \\
\hline Kaart et al. (2010) & $99 \%<7 \mathrm{~d}$ & Yes & Optigraph & $35^{\circ} \mathrm{C}$ & Milase 750 & 0.150 & - & - & 10.4 & - & - & $13.6^{8}$ \\
\hline Penasa et al. (2010) & $3 \mathrm{~h}$ & No & CRM & $35^{\circ} \mathrm{C}$ & Hansen 190 & 0.061 & 31 & 9.7 & 16.9 & - & - & 32.0 \\
\hline Cecchinato et al. (2011b) & $3 \mathrm{~h}$ & No & CRM & $35^{\circ} \mathrm{C}$ & Hansen 190 & 0.061 & 31 & 3.5 & 15.0 & - & - & 41.7 \\
\hline Cecchinato et al. (2011b) & $3 \mathrm{~h}$ & No & CRM & $35^{\circ} \mathrm{C}$ & Hansen 190 & 0.061 & 31 & 9.7 & 16.9 & - & - & 29.2 \\
\hline Bonfatti et al. (2011) & $3 \mathrm{~h}$ & Yes & CRM & $35^{\circ} \mathrm{C}$ & Hansen 190 & 0.061 & 31 & 6.3 & 16.5 & - & - & 29.1 \\
\hline Cecchinato et al. (2011a) & $1 \mathrm{~d}$ & No & Formagraph & $35^{\circ} \mathrm{C}$ & Hansen 160 & 0.051 & 90 & 6.7 & 19.9 & 0.1 & 5.4 & 30.2 \\
\hline
\end{tabular}

${ }^{1}$ Formagraph (Foss Electric A/S, Hillerød, Denmark); CRM (Polo Trade, Monselice, Italy); Optigraph (Ysebaert SA, Frépillon, France).

${ }^{2}$ Renco rennet (Renco New Zealand, Eltham. New Zealand); Renco calf rennet liquid (RCRL, New Zealand Rennet Company Ltd., Eltham, New Zealand); Hansen 190 rennet

c. (PacovisAmrein AG, Bern, Switzerland); Milase 750 rennet (CSK Food Enrichment BV, Ede, the Netherlands); Hansen 160 rennet (PacovisAmrein AG).

${ }^{3} \mathrm{IMCU}=$ international milk clotting unit; $\mathrm{RCT}=$ rennet coagulation time (average values calculated on coagulating samples); $\mathrm{k}_{20}=$ curd-firming time; $\mathrm{a}_{30}=$ curd firmness.

$\stackrel{4}{4}$ Average of curd firmness 10 min after coagulation $\left(\mathrm{a}_{10}\right)$

글 ${ }^{5}$ Average estimate excluding the NC samples, which were included giving them a value of $0.0 \mathrm{~mm}$.

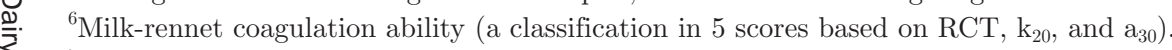

( ) ${ }^{7}$ Estimated as anti-ln of the average of $\ln (\mathrm{RCT})$, as reported by the authors.

임 ${ }^{8}$ Expressed in volts. 
6854

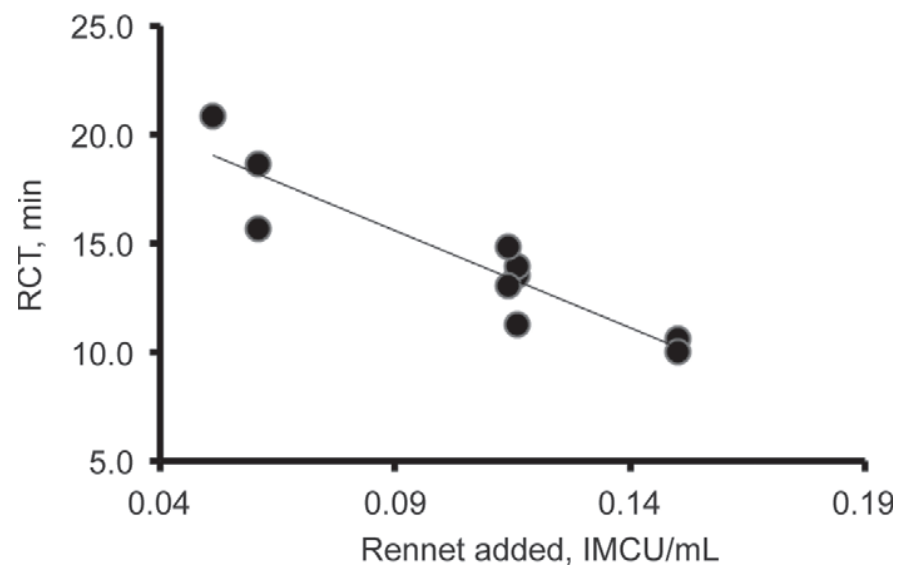

Figure 6. Relationship between rennet coagulation time (RCT min) and the quantity of rennet added to milk expressed in international milk clotting units (IMCU, units $/ \mathrm{mL}$; $\mathrm{RCT}=23.8-91.0$ IMCU; $\left.\mathrm{R}^{2}=0.82\right)$.

According to Bittante (2011), the major limitations of traditional MCP estimation are (1) the existence of NC samples, (2) problems associated with acquisition of $\mathrm{k}_{20}$ values and the repeatability of the measurements, and (3) the nature of the information yielded by $\mathrm{a}_{30}$ and the correlation of $\mathrm{a}_{30}$ with RCT. Many authors have reported the proportion of samples that did not coagulate within the 30-min duration of standard lactodynamographic analysis. Kaart et al. (2010) did not report exact figures but affirmed that the proportion of NC samples was very low. The values ranged from 0.0 to $19.0 \%$ (Table 5 ), and the proportion of NC samples appears to be more closely associated with the cow's breed than with the concentration of rennet. Among the breeds, the Ayrshire and Friesian showed the highest incidence of NC milks (Tables 5 and 6).

When the lactodynamographic test is conducted over the usual 30-min interval, the proportion of samples that do not attain a curd firmness of at least $20 \mathrm{~mm}$ before the end of the trial is very high, to the extent that most recent reports do not even consider this trait. Past studies reported that the frequency of samples without a measure of $\mathrm{k}_{20}$ ranged from 8.4 to $32.9 \%$ (Table 5). Only Tervala et al. (1985) and Ikonen et al. $(1997,1999 \mathrm{a})$ have reported average $\mathrm{k}_{20}$ values of samples exhibiting this trait. Recently, Cecchinato et al. (2011a) obtained a $k_{20}$ value for $99.9 \%$ of analyzed samples, but this was possible only because the observation period was extended to 90 min (Cipolat-Gotet et al., 2012).

With the exception of Tervala et al. (1985), all studies reported values of curd firmness that were obtained 30 or $31 \mathrm{~min}$ after enzyme addition (the values are termed $\mathrm{a}_{30}$ or $\mathrm{E}_{30}$ ). Most authors reported average values from samples that coagulated within $30 \mathrm{~min}$, but others (Ikonen et al., 1999a; Tyrisevä et al., 2004; Cecchinato et al., 2011a) included the null values obtained for $\mathrm{NC}$ samples when calculating the means. To facilitate comparisons among such estimates, the values of the 3 reports (Ikonen et al., 1999a; Tyrisevä et al., 2004; Cecchinato et al., 2011a) have been recalculated to yield average values estimated after exclusion of $\mathrm{NC}$ samples (Table 5).

\section{Genetic Parameters of MCP Estimated in Different Breeds}

The first estimate of heritability for MCP was reported by Lindström et al. (1984), who sampled 731 Finnish Ayrshire cows once. Cows were progeny of 20 bulls and differed in terms of parity and DIM (Table 6 ). The following 3 reports sought to estimate genetic parameters of MCP as part of research projects exploring the effects of genetic variants of milk proteins on MCP in cows of different breeds. Tervala et al. (1985) studied 319 cows sampled in mid lactation; the animals were of 3 breeds (169 Finnish Ayrshire cows sired by 6 bulls, 93 Finnish Friesian cows sired by 5 bulls, and 58 local Finncattle cows sired by 7 bulls; all data were pooled because no breed effect was significant upon preliminary analysis). Oloffs et al. (1992) genotyped a large number of cows (3,346 German Friesians sired by 92 bulls and 1,507 Angler cows sired by 45 bulls). Last, Ikonen et al. (1997) genotyped cows on 2 experimental farms (one had 59 Finnish Ayrshire cows sired by 25 bulls and the other 55 Finnish Friesian cows sired by 32 bulls). However, in the latter report, testing was repeated 1,3 , and 5 mo after calving.

At the end of the last century, Ikonen et al. (1999a) reported heritability estimates obtained from a study on 895 cows, mainly Finnish Ayrshire. Three years later, Bittante et al. (2002) used a longitudinal database containing information on 6,909 repeated samples of 547 Italian Holstein cows of a single herd to estimate heritability of RCT. More recently, several heritability estimates have appeared in the literature. Most data were obtained via single sampling of herds on large data sets (913 to 4,664 cows). Finnish Ayrshire, Friesian, and crossbred cows have been examined (Ikonen et al., 2004; Tyrisevä et al., 2004), as have Italian Friesian cows (Cassandro et al., 2008; Penasa et al., 2010; Cecchinato et al., 2011b), Brown Swiss cows (Cecchinato et al., 2009, 2011a,b), and Simmental cows (Bonfatti et al., 2011). Finally, studies on Estonian Friesian cows have accessed a very large database containing repeated measures (Kaart et al., 2010; Vallas et al., 2010). 
Table 6. Breed, average daily milk yield (MY), number of samples and animals, type of model and factors included in the statistical analysis of milk coagulation properties for the estimation of heritability ${ }^{1}$

\begin{tabular}{|c|c|c|c|c|c|c|c|c|c|c|c|}
\hline Reference & Breed $^{2}$ & $\begin{array}{l}\mathrm{MY} \\
\mathrm{kg} / \mathrm{d}\end{array}$ & $\begin{array}{l}\text { Samples, } \\
\text { no. }\end{array}$ & $\begin{array}{c}\text { Cows, } \\
\text { no. }\end{array}$ & $\begin{array}{l}\text { Sires, } \\
\text { no. }\end{array}$ & Model & Parity & DIM & $\begin{array}{l}\text { Herds, } \\
\text { no. }\end{array}$ & Herd & Other \\
\hline Lindström et al. (1984) & Ay & - & 731 & 731 & 20 & Sire & $4 \mathrm{cl}$ & $5 \mathrm{cl}$ & $?$ & No & $\begin{array}{l}\text { Mastitis, lactose } \\
\text { regression }\end{array}$ \\
\hline Tervala et al. (1985) & $\begin{array}{l}\text { Ay, HF, } \\
\text { FC }\end{array}$ & - & 319 & 319 & 18 & Sire & $4 \mathrm{cl}$ & $\begin{array}{l}\text { Linear } \\
\text { regression }\end{array}$ & $?$ & No & Season (3 cl.) \\
\hline Oloffs et al. (1992) & $\mathrm{HF}$ & - & - & 3,346 & 92 & Sire & $?$ & Yes (?) & $\sim 1,400$ & $3 \mathrm{cl}$. & \\
\hline Oloffs et al. (1992) & An & - & - & 1,507 & 45 & Sire & $?$ & Yes (?) & $\sim 1,400$ & $3 \mathrm{cl}$ & \\
\hline Ikonen et al. (1997) & Ay & - & 174 & 59 & 25 & Animal & $3 \mathrm{cl}$. & $1,3,5 \mathrm{mo}$ & 1 & No & $\begin{array}{l}\beta-\kappa-\mathrm{CN}+\beta-\mathrm{LG} \\
\text { genotype, season } \\
(4 \mathrm{cl} .)\end{array}$ \\
\hline Ikonen et al. (1997) & $\mathrm{HF}$ & - & 155 & 55 & 32 & Animal & $3 \mathrm{cl}$ & $1,3,5 \mathrm{mo}$ & 1 & No & $\begin{array}{l}\beta-\kappa-\mathrm{CN}+\beta-\mathrm{LG} \\
\text { genotype, season } \\
(4 \mathrm{cl} .)\end{array}$ \\
\hline Ikonen et al. (1999a) & Ay, HF & 24.8 & 895 & 895 & 287 & Animal & $4 \mathrm{cl}$ & $6 \mathrm{cl}$ & 51 & Fixed & Breed (2) \\
\hline Bittante et al. (2002) & $\mathrm{HF}$ & 28.8 & 6,909 & 517 & - & Animal & $12 \mathrm{cl}^{3}$ & $7 \mathrm{cl}$ & 1 & & Test dates (40), PE \\
\hline Tyrisevä et al. (2004) & $\begin{array}{l}\text { Ay, HF, } \\
\text { CB }\end{array}$ & 24.2 & 1,408 & 1,408 & 547 & Animal & $4 \mathrm{cl}$ & $11 \mathrm{cl}$ & 125 & Random & $\begin{array}{l}\text { Breed (3), instr. } \\
\text { units (20) }\end{array}$ \\
\hline Ikonen et al. (2004) & Ay & 24.3 & 4,664 & 4,664 & 91 & Animal & $3 \mathrm{cl}$. & $14 \mathrm{cl}$ & 693 & Random & $\begin{array}{l}\text { S. age }(12 \text { cl. }) \text {, instr. } \\
\text { units }(20)\end{array}$ \\
\hline Cassandro et al. (2008) & $\mathrm{HF}$ & 32.3 & 1,042 & 1,042 & 54 & Animal & $3 \mathrm{cl}$ & $14 \mathrm{cl}$. & 34 & Fixed & \\
\hline Cecchinato et al. (2009) & BS & 28.6 & 1,200 & 1,200 & 50 & Animal & $3 \mathrm{cl}$ & $10 \mathrm{cl}$ & & & \\
\hline Vallas et al. (2010) & $\mathrm{HF}$ & 25.9 & 17,577 & 4,191 & 274 & Animal & First $^{4}$ & $\mathrm{DIM}+\mathrm{DIM}^{2}$ & 73 & Random & PE, year-season \\
\hline Kaart et al. (2010) & $\mathrm{HF}$ & 26.0 & 18,825 & 5,007 & - & Animal & First $^{4}$ & $\begin{array}{l}\mathrm{DIM}^{3} \\
\mathrm{DIM}^{3}\end{array}$ & & Random & $\begin{array}{l}\text { PE, year-season, } \\
\text { sample age }\end{array}$ \\
\hline Penasa et al. (2010) & $\mathrm{HF}$ & 32.3 & 1,025 & 1,025 & 54 & Animal & $3 \mathrm{cl}$ & $14 \mathrm{cl}$ & 34 & Fixed & $\beta-\kappa-\mathrm{CN}$ genotype \\
\hline Cecchinato et al. (2011b) & BS & 28.6 & 1,234 & 1,234 & 58 & Animal & $3 \mathrm{cl}$. & $10 \mathrm{cl}$ & 38 & Random & Linear censored \\
\hline Cecchinato et al. (2011b) & $\mathrm{HF}$ & 32.4 & 1,025 & 1,025 & 54 & Animal & $3 \mathrm{cl}$ & $10 \mathrm{cl}$. & 34 & Random & Linear censored \\
\hline Bonfatti et al. (2011) & $\mathrm{Si}$ & - & 2,167 & 2,167 & - & Animal & $4 \mathrm{cl}$ & $12 \mathrm{cl}$ & 47 & Fixed & $\begin{array}{l}\beta \text { - }-\mathrm{CN}+\beta-\mathrm{LG} \\
\text { genotype }\end{array}$ \\
\hline Cecchinato et al. (2011a) & BS & 24.4 & 913 & 913 & 140 & Animal & $4 \mathrm{cl}$ & $6 \mathrm{cl}$ & 63 & Random & \\
\hline
\end{tabular}




\section{Genetic Parameters of MCP Estimated Using Different Models}

A summary of the main features of the statistical model used to estimate genetic parameters for MCP is shown in Table 6 . All of the reports that have appeared in the interval since the contribution of Ikonen et al. (1997) have used animal models; the earlier studies investigated paternal half-sibling groupings (Lindström et al., 1984; Tervala et al., 1985; Oloffs et al., 1992). Oloffs et al. (1992) also performed dam-daughter regression. As the last method yielded unrealistically high heritability estimates, only the values obtained using paternal half-sibling comparisons will be discussed.

All models included a factor reflecting cow age (Table 6 ); this was usually parity (divided into 3 or 4 classes) or age of the cow at sampling (divided into 12 classes; Bittante et al., 2002). Linear regression on age at first calving was used when only primiparous cows were sampled (Kaart et al., 2010; Vallas et al., 2010). Often, the effect of cow age or parity was not significant or, if it was, the relevance of the effect was low.

Lactation stage was always included in earlier models, usually via use of classes of DIM, because MCP tend to be favorable at the beginning of the lactation (low RCT and high $\mathrm{a}_{30}$ ) and less favorable in mid lactation, with a tendency to recover at the end of lactation (CipolatGotet et al., 2012). Ikonen et al. (1997) sampled all experimental cows 3 times at fixed intervals on the lactation curve and included sampling data obtained at 1,3 , and 5 mo in their model. Tervala et al. (1985) used linear regression on DIM in the analysis. Vallas et al. (2010) explored both the linear and quadratic effects of DIM, whereas Kaart et al. (2010) evaluated any possible cubic effect of DIM.

The herd effect has been modeled differently by various authors. Ikonen et al. (1997) and Bittante et al. (2002) did not include a herd effect in their analysis as they operated in one herd. Lindström et al. (1984) and Tervala et al. (1985) did not analyze any possible herd effect, although these authors collected samples from several herds. Oloffs et al. (1992) sampled animals on about 1,400 farms, and separated them into 3 classes based on average milk production level. Ikonen et al. (1999a), Cassandro et al. (2008), and Penasa et al. (2010) worked on more than 30 farms and included the fixed effect of the herd in their models. Finally, Tyrisevä et al. (2004), Ikonen et al. (2004), Kaart et al. (2010), and Vallas et al. (2010) sampled a large number of farms (73 to 693) and included this effect as random effect in modeling MCP data (Table 6).

The effect of cow breed has also been considered in different ways. Oloffs et al. (1992) and Cecchinato et al. (2011b) computed genetic parameters for each breed.
However, other researchers pooled data obtained from different breeds, but included breed as a fixed effect upon modeling (Ikonen et al., 1999a; Tyrisevä et al., 2004). Tervala et al. (1985) pooled data without including breed in modeling because the breed effect was not significant in the preliminary ANOVA.

Other effects have also been included in models used to estimate the contribution of additive genetic variance to MCP. Seasonal effects were considered by authors who did not include a herd effect in the models (Tervala et al., 1985; 3 seasonal classes were evaluated) or who repeatedly sampled the same cows (Ikonen et al., 1997; Bittante et al., 2002; Kaart et al., 2010). Mastitis was considered relevant by Lindström et al. (1984), who also included viscometric milk data (again graded in classes) and linear regression based on lactose content in the analysis. Genetic variants of milk proteins were included in the models of Ikonen et al. (1997) and Penasa et al. (2010). Finally, methodological research aspects have been considered; the models of both Tyrisevä et al. (2004) and Ikonen et al. (2004) included instrumental unit used for each sample $(20$ units), because preliminary analysis revealed that this source of variation was significant. In addition, Tyrisevä et al. (2004), Ikonen et al. (2004), and Kaart et al. (2010) included the time interval between sample collection and analysis when constructing models. This lag time varied between 1 and $29 \mathrm{~d}$ (Table 6).

\section{Heritability of MCP}

Table 7 summarizes heritability estimates of MCP obtained by different authors and compares these values with those obtained for major milk traits. When studies reported heritability of MCP determined by different instruments or models, the more conventional approaches were favored in the present review. The other approaches will be discussed later.

Excluding the data of Ikonen et al. (1997), who studied only very few animals, and of Bittante et al. (2002), who developed a trait that sought to combine RCT and $\mathrm{a}_{30}$, the heritability of RCT calculated from 15 papers is $0.26 \pm 0.06$. Except for some old reports, most heritabilities are very similar, being between 0.21 and 0.34. Further, heritability does not seem to be notably influenced by any population characteristic, analytical methodology, or modeling.

The heritability of $\mathrm{a}_{30}(0.27 \pm 0.11)$ is similar to that of RCT but shows large variation among studies. It appears that the rennet concentration used influences heritability because trials that used greater amounts of rennet tended to obtain higher estimates of heritability. This variability can be explained (1) by observing that $a_{30}$ values obtained using different rennet concentra- 
Table 7. Heritability $\left(\mathrm{h}^{2}\right)$ estimates of milk coagulation properties (RCT, $\mathrm{k}_{20}$, and $\mathrm{a}_{30}{ }^{1}$ ), yield (MY), quality (fat \%, protein $\%$, and casein $\%$ ), acidity ( $\mathrm{pH}$ and titratable acidity, TA), and SCS

\begin{tabular}{|c|c|c|c|c|c|c|c|c|c|c|}
\hline \multirow[b]{2}{*}{ Reference } & \multicolumn{10}{|c|}{ Property } \\
\hline & $\mathrm{RCT}$ & $\mathrm{k}_{20}$ & $\mathrm{a}_{30}$ & MY & Fat $\%$ & Protein $\%$ & Casein \% & $\mathrm{pH}$ & TA & SCS \\
\hline Lindström et al. (1984) & $0.27^{2}$ & - & - & - & - & - & - & - & - & - \\
\hline Tervala et al. (1985) & 0.13 & 0.02 & $0.25^{3}$ & - & - & - & - & - & - & - \\
\hline Oloffs et al. (1992) & 0.27 & - & 0.30 & - & - & - & - & 0.24 & - & - \\
\hline Oloffs et al. (1992) & 0.38 & - & 0.39 & - & - & - & - & 0.24 & - & - \\
\hline Ikonen et al. (1997) & $0.62^{4}$ & 0.54 & $0.41^{4}$ & 0.12 & 0.37 & 0.34 & 0.50 & 0.08 & - & $0.18^{4}$ \\
\hline Bittante et al. (2002) & $0.40^{4,6}$ & - & - & 0.22 & - & - & - & - & - & 0.09 \\
\hline Tyrisevä et al. (2004) & 0.21 & - & 0.22 & 0.14 & 0.16 & 0.32 & - & 0.18 & - & - \\
\hline Ikonen et al. (2004) & 0.28 & - & 0.22 & 0.13 & 0.18 & 0.29 & 0.35 & 0.38 & - & 0.06 \\
\hline Cassandro et al. (2008) & 0.25 & - & 0.15 & 0.09 & 0.39 & 0.30 & 0.35 & 0.21 & 0.17 & 0.07 \\
\hline Cecchinato et al. (2009) & 0.32 & - & 0.24 & - & - & - & - & - & - & - \\
\hline Vallas et al. (2010) & 0.28 & - & 0.41 & 0.15 & 0.19 & 0.28 & - & 0.24 & - & 0.05 \\
\hline Kaart et al. (2010) & 0.34 & - & 0.44 & 0.16 & 0.25 & 0.30 & - & 0.28 & - & 0.06 \\
\hline Estimates, no. & 15 & 4 & 15 & 12 & 11 & 11 & 8 & 13 & 4 & 9 \\
\hline Average heritability & 0.26 & 0.36 & 0.27 & 0.14 & 0.27 & 0.31 & 0.33 & 0.21 & 0.20 & 0.08 \\
\hline $\mathrm{SD}$ & 0.06 & 0.29 & 0.11 & 0.08 & 0.12 & 0.07 & 0.09 & 0.10 & 0.02 & 0.03 \\
\hline
\end{tabular}

${ }^{1} \mathrm{RCT}=$ rennet coagulation time; $\mathrm{k}_{20}=$ curd-firming time; $\mathrm{a}_{30}=$ curd firmness.

${ }^{2}$ The heritability estimate was 0.23 excluding the cows affected by mastitis.

${ }^{3}$ Curd firmness measured 10 min after coagulation $\left(\mathrm{a}_{10}\right)$.

${ }^{4}$ Data excluded from the calculation of the average value and SD.

${ }^{5}$ Noncoagulating samples included ( $\left.\mathrm{NC}: \mathrm{a}_{30}=0.0 \mathrm{~mm}\right)$.

${ }^{6}$ Heritability of milk-rennet coagulation ability (a classification in 5 scores based on RCT, $\mathrm{k}_{20}$, and $\mathrm{a}_{30}$ ).

tions are effectively distinct, and (2) by noting that the inclusion of $\mathrm{NC}$ data in analysis greatly affects average $\mathrm{a}_{30}$ (because the $\mathrm{a}_{30}$ value of a NC sample is zero).

Only 4 estimates of heritability for $\mathrm{k}_{20}$ are available (Table 7 ). The first 3 were obtained many years ago in Finland on a very small number of cows. Tervala et al. (1985) found that heritability for $\mathrm{k}_{20}$ was almost zero, whereas heritability estimates from Ikonen et al. (1997) were very high. Recently, Cecchinato et al. (2011a), with a prolonged observation period, obtained $\mathrm{k}_{20}$ values for almost all cows sampled and estimated heritability to be intermediate between those of previous studies.

Heritability estimates for MCP were almost double those for milk yield (Table 7). In fact, all 12 papers obtained heritability estimates for RCT and $\mathrm{a}_{30}$ that were higher than those for milk yield, with the only exception being Ikonen et al. (1999a), who found that only $\mathrm{a}_{30}$ was more heritable than milk yield. Eleven papers (Table 7) found that, on average, the heritability of MCP was similar to that of milk quality traits (fat, protein, and casein percentages) estimated under the same conditions. The average heritability for other milk traits important for cheese-making ability were either somewhat lower ( $\mathrm{pH}$ and titratable acidity) or much lower (SCS) than that of MCP (Table 7).

Some reports on heritability have sought to explore herd-derived variance (Ikonen et al., 2004; Tyrisevä et al., 2004; Vallas et al., 2010). In addition, the individual repeatability of measured traits during lactation was considered by Ikonen et al. (1997), Tyrisevä et al. (2003), and Vallas et al. (2010). The average values of these estimates are summarized in Figure 7, which also shows the average values of heritability and individual repeatability. Both RCT and $\mathrm{a}_{30}$ were only marginally affected by herd effect, being much less influenced than milk yield and fat content. Several reports have canvassed the effects of farming systems, and especially feeding regimens, on MCP. It is evident that the improvement of MCP is fundamentally affected by genetics; all other tested factors associated with herd management (feeding, milking, and hygiene protocols, barn accommodation) did not significantly affect MCP.

The average repeatability of estimates of RCT and $a_{30}$ was higher than that of milk yield or fat content. This means that it is possible to sample cows on only a few occasions, or only once, to characterize milk proper- 
6858

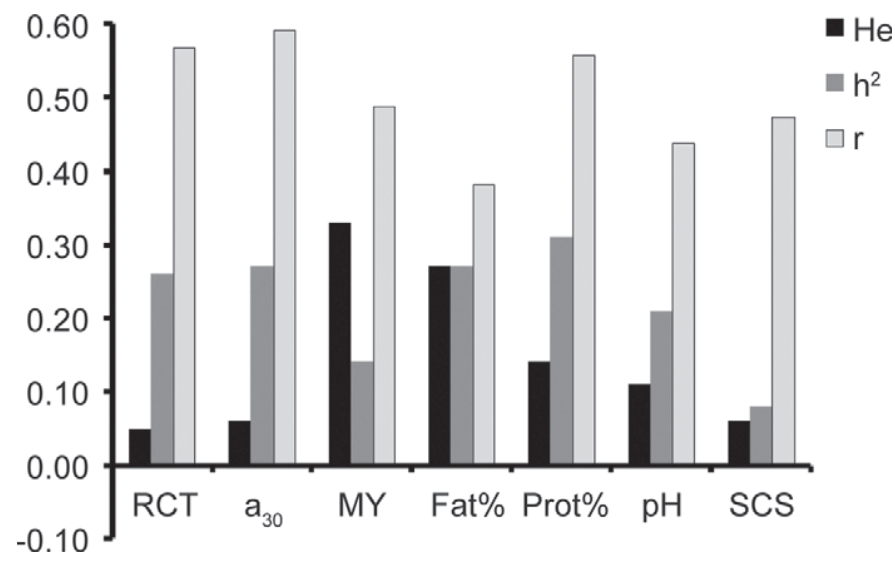

Figure 7. Average values of herd effect $(\mathrm{He})$, heritability $\left(h^{2}\right)$, and repeatability $(\mathrm{r})$ values for rennet coagulation time (RCT), curd firmness $\left(\mathrm{a}_{30}\right)$, and other milk traits (MY: daily milk yield; Fat\%: fat content; Prot\%: protein content; pH: acidity. Herd effect was averaged from Ikonen et al. (2004), Tyrisevä et al. (2004), and Vallas et al. (2010), and the SD were between 0.01 and 0.10 with the exception of fat \% (0.21). Heritabilities are the means of estimates summarized in Table 7 (SD of the means are also in Table 7). Repeatability was averaged from Ikonen et al. (1997), Tyrisevä et al. (2003), and Vallas et al. (2010), and the SD were between 0.05 and 0.08 .

ties. This also justifies the validity of most heritability estimates in the literature that are based on analysis of a single sample of milk per cow.

\section{Genetic Association of MCP with Milk Acidity and Casein Content}

Most reports seeking to estimate heritability for MCP have also examined genetic and phenotypic correlations among the studied traits. First, it is possible to discern from the data summarized in Table 8 that RCT and $\mathrm{a}_{30}$ are strongly and negatively correlated, both phenotypically and genetically. Moreover, the variability of the estimates is relatively low. This means that RCT (or $\mathrm{a}_{30}$ ) adds very little new information to that yielded by $\mathrm{a}_{30}$ (or RCT), especially from a genetic viewpoint. This is particularly true for estimates obtained using data characterized by high RCT values, such as those gathered in studies on Holstein-Friesian cows or from samples to which low amounts of rennet have been added. It is evident that the longer the time needed for coagulation, the less informative is the value of $\mathrm{a}_{30}$. No information is available on genetic correlations involving $\mathrm{k}_{20}$, although this trait is of considerable practical importance.

The observed phenotypic and genetic correlations between milk yield and either of the $2 \mathrm{MCP}$ are rather variable and sometimes contradictory. In any event, the average correlations are low (Table 8), suggesting that selection for high milk yield should have a small effect on MCP.

Turning to relationships between MCP and milk quality traits, it is evident that RCT exhibits very low phenotypic and genetic correlations with milk quality data (fat, protein, and casein contents). The variability of genetic correlations is very high, which means that both favorable and unfavorable values are well represented.

For $\mathrm{a}_{30}$, the results are more consistent and, although high variability is evident among estimates, it appears that the phenotypic and genetic relationships between $\mathrm{a}_{30}$ and milk quality are high. This is especially true when protein and casein levels are considered (Table 8). Selection to improve milk contents, especially casein, should thus moderately favor enhanced $\mathrm{a}_{30}$.

Table 8. Phenotypic $\left(\mathrm{r}_{\mathrm{P}}\right)$ and additive genetic $\left(\mathrm{r}_{\mathrm{A}}\right)$ correlations between milk coagulation properties ${ }^{1}$ and milk yield (MY), quality (fat \%, protein $\%$, and casein $\%$ ), acidity (pH and titratable acidity, TA), and SCS

\begin{tabular}{|c|c|c|c|c|c|c|c|c|c|}
\hline \multirow[b]{3}{*}{ Property } & \multicolumn{4}{|c|}{$\mathrm{RCT}$} & \multicolumn{4}{|c|}{$\mathrm{a}_{30}$} & \multirow[b]{3}{*}{ References $^{2}$} \\
\hline & \multicolumn{2}{|c|}{$r_{P}$} & \multicolumn{2}{|c|}{$\mathrm{r}_{\mathrm{A}}$} & \multicolumn{2}{|c|}{$\mathrm{r}_{\mathrm{P}}$} & \multicolumn{2}{|c|}{$\mathrm{r}_{\mathrm{A}}$} & \\
\hline & Mean & $\mathrm{SD}$ & Mean & SD & Mean & SD & Mean & SD & \\
\hline $\mathrm{a}_{30}$ & -0.81 & 0.10 & -0.92 & 0.05 & - & - & - & - & $2,3,5,7,8,9,10,11,12$ \\
\hline MY & -0.06 & 0.08 & -0.15 & 0.18 & -0.03 & 0.04 & 0.04 & 0.22 & $3,5,6,7,8,9,10,11$ \\
\hline Fat $\%$ & -0.07 & 0.05 & -0.06 & 0.36 & 0.06 & 0.09 & 0.13 & 0.14 & $1,2,5,7,8,9,10,11,13$ \\
\hline TA & -0.43 & - & -0.51 & 0.13 & 0.41 & - & 0.74 & 0.13 & $8,10,11$ \\
\hline SCS & 0.15 & 0.10 & 0.16 & 0.34 & -0.05 & 0.08 & -0.38 & 0.27 & $1,5,6,7,8,9,10,11,13$ \\
\hline
\end{tabular}

${ }^{1} \mathrm{RCT}=$ rennet coagulation time; $\mathrm{a}_{30}=$ curd firmness.

${ }^{2} 1=$ Lindstrom et al. (1984; only with RCT, viscosity of milk instead of SCS); $2=$ Tervala et al. $\left(1985 ;\right.$ only $\mathrm{r}_{\mathrm{P}}, \mathrm{a}_{10}$ instead of $\left.\mathrm{a}_{30}\right) ; 3=$ Oloffs et al. (1992; only $\left.\mathrm{r}_{\mathrm{A}}\right) ; 4=$ Ikonen et al. (1997; only $\mathrm{r}_{\mathrm{P}}$, calculated from linear regression coefficients); $5=$ Ikonen et al. (1999a; only $\mathrm{r}_{\mathrm{A}}$ ); $6=$ Bittante et al. (2002; with milk-rennet coagulation time); $7=$ Ikonen et al. (2004); $8=$ Cassandro et al. $(2008) ; 9=$ Vallas et al. $(2010) ; 10=$ Penasa et al. (2010; only $\left.\mathrm{r}_{\mathrm{A}}\right) ; 11=$ Cecchinato et al. $\left(2011 \mathrm{~b}\right.$; only $\left.\mathrm{r}_{\mathrm{A}}\right) ; 12=$ Bonfatti et al. (2011); $13=$ Cecchinato et al. (2011a; only $\mathrm{r}_{\mathrm{A}}$ with $\mathrm{RCT}$, testing time of $90 \mathrm{~min})$. 
Table 9. Influence of inclusion of composite casein genotypes (CCG) in linear model on the estimation of variance components and heritability of milk coagulation properties ${ }^{1}$ (measured on individual milk samples of Holstein-Friesian cows; Penasa et al., 2010)

\begin{tabular}{|c|c|c|c|c|}
\hline \multirow[b]{2}{*}{ Trait $^{2}$} & \multicolumn{2}{|c|}{$\mathrm{RCT}, \min$} & \multicolumn{2}{|c|}{$\mathrm{a}_{30}, \mathrm{~mm}$} \\
\hline & $\operatorname{Lin}^{3}$ & $\operatorname{Lin}+\mathrm{CCG}^{4}$ & Lin & Lin + CCG \\
\hline$\sigma_{A}^{2}$ & 4.4 & 2.3 & 13.0 & 4.1 \\
\hline$\sigma_{E}^{2}$ & 13.3 & 13.9 & 92.8 & 92.6 \\
\hline$h^{2}$ & 0.25 & 0.14 & 0.12 & 0.04 \\
\hline
\end{tabular}

Acidity is the characteristic of milk that is more closely correlated with MCP, both phenotypically and genetically (Table 8). The importance of $\mathrm{pH}$ in terms of coagulation, curd firming, and syneresis has been well documented experimentally for decades (Kowalchyk and Olson, 1977; Okigbo et al., 1985d; Calvo and Balcones, 2000; Bencini, 2002; Nájera et al., 2003). The high average estimates of genetic correlations of both $\mathrm{pH}$ and titratable acidity with MCP, coupled with acceptable variability of the estimates, indicate that these traits can be efficiently exploited for indirect selection of desirable MCP.

The observed correlations between SCS and MCP are variable and sometimes contradictory (Table 8), but, on average, the SCS trait exerts unfavorable phenotypic and genetic effects on both RCT and $\mathrm{a}_{30}$; this is especially true when genetic relationships between SCS and $\mathrm{a}_{30}$ are considered.

\section{Milk Protein Genotypes Contribute Genetic Variability to $M C P$}

The genetic parameters examined above were estimated using classical linear models that did not include genotypic information from specific loci. As milk protein variants exert strong effects on MCP, it is clearly important to include this information in a statistical model.

Penasa et al. (2010) compared genetic parameters estimated using a classical linear animal model with those obtained when the $\beta$ - $\kappa$-casein composite genotype was included in such a model. Incorporation of milk protein genetic variants reduced the estimate of the additive genetic variances for RCT and $\mathrm{a}_{30}$ by 48 and $68 \%$, respectively (Table 9 ). As error variances did not change in the models with or without the inclusion of $\beta$ - $\kappa$-casein composite genotypes, the heritability estimates decreased accordingly. Ikonen et al. (1999a) reported that using a similar approach and estimating heritability of MCP by including $\beta$ - $\kappa$-casein composite genotypes and $\beta-\mathrm{LG}$ genotype, the additive genetic variances of RCT and $\mathrm{a}_{30}$ decreased by 20 and $24 \%$, respectively. Some differences among the various reports are expected as the methodology, experimental conditions, and populations are often different. It seems clear that the proportion of additive genetic variance explained by any particular locus is influenced by allele frequency. In other words, that proportion will increase as the allele frequencies become more balanced.

The variation at lactoprotein-encoding loci can be used to select indirectly for desirable MCP, but the results will vary depending on experimental conditions and, especially, the frequencies of the different alleles in the studied population. In any case, a significant proportion of genetic variation for MCP is independent of variation in milk protein variants (being attributable to variation in other major genes and polygenes). If variation in milk protein-encoding genes is to be exploited toward MCP selection, a specific breeding program is needed.

Penasa et al. (2010) have shown that estimates of some genetic correlations can be influenced by inclusion of milk protein variants in modeling. In particular, the correlations between the values of both RCT and $\mathrm{a}_{30}$, on the one hand, and milk yield and SCS, on the other hand, were higher when a model including $\beta$ - $\kappa$-casein composite genotypes was used. Correlations between MCP and milk yield became more favorable and those with SCS more unfavorable when the model included data on milk protein variants.

We can speculate that inclusion of milk protein variants in a breeding program that seeks to improve MCP increases the power of selection and beneficially exploits the observed correlations between such parameters and other traits. Thus, milk acidity appears to be less influenced by variation in milk proteins variants 
Table 10. Estimation of genetic parameters of milk coagulation properties measured on individual milk samples of 4,664 Finnish Ayrshire cows using an animal linear model and treating rennet coagulation time (RCT) of coagulated sample (CO) as a Gaussian variable, and curd firmness $\left(\mathrm{a}_{30}\right)$ as binary variable or as Gaussian variable considering only $\mathrm{CO}$ or all samples assigning to noncoagulating samples a value of zero (Ikonen et al., 2004)

\begin{tabular}{|c|c|c|c|c|}
\hline \multirow[b]{2}{*}{ Item } & \multirow{2}{*}{$\underset{\mathrm{CO}^{1}}{\mathrm{RCT}, \min }$} & \multicolumn{3}{|c|}{$\mathrm{a}_{30}, \mathrm{~mm}$} \\
\hline & & Binary $^{2}$ & $\mathrm{CO}^{1}$ & $\mathrm{CO}+\mathrm{NC}^{3}$ \\
\hline Observations, no. & 4,038 & 4,664 & 4,046 & 4,664 \\
\hline Mean value & 11.8 & 0.90 & 27.6 & 24.0 \\
\hline Heritability $\left(h^{2}\right)$ & 0.28 & 0.26 & 0.22 & 0.39 \\
\hline
\end{tabular}

${ }^{1}$ Using the data measured by computerized renneting meter on samples that coagulated (CO).

${ }^{2}$ Giving a value of 0 to noncoagulated (NC) samples and a value of 1 to $\mathrm{CO}$ samples.

${ }^{3}$ Using the data measured by computerized renneting meter to $\mathrm{CO}$ samples and giving a value of 0 to $\mathrm{NC}$ samples.

but is nonetheless the trait that shows the highest correlation with MCP. Acidity is thus the most promising candidate for use in indirect selection.

\section{MODELING OF MCP}

\section{Noncoagulating Milk}

The proportion of milk samples that do not coagulate within the usual 30-min observation period depends principally on the breed of cow (Holstein-Friesian and northern breeds yield more NC milk), the quantity of rennet used (an increase in IMCU level lowers the proportion of $\mathrm{NC}$ samples), and milk acidity (lower $\mathrm{pH}$ reduces the proportion of $\mathrm{NC}$ samples). The RCT values are not available for $\mathrm{NC}$ samples (coagulation does not establish within $30 \mathrm{~min}$ ); $\mathrm{a}_{30}$ values cannot be calculated (zero may be an appropriate datum?); and, obviously, $\mathrm{k}_{20}$ cannot be estimated (the value is simply missing).

Noncoagulation of milk is important in the dairy industry but is very difficult to model in any estimation of genetic parameters and breeding values of animals. In earlier work, data from NC samples were not included in statistical analysis because RCT was unavailable and the linear models used could not accommodate information on NC milk. The report of Ikonen et al. (2004) was the first to identify the problem. The authors analyzed $a_{30}$ values obtained from a very large data set of Finnish Ayrshire cows as a binary $(0,1)$ trait and calculated a heritability of 0.26 (Table 10). The treatment of $\mathrm{a}_{30}$ as binary is identical to treating RCT as binary. The RCT heritability derived using coagulating samples and analyzed under a linear animal model, was very similar (0.28). Analysis of $\mathrm{a}_{30}$ values of coagulating samples in the same model yielded a slightly lower heritability (0.22). However, when data on the NC samples were included in the analysis, the $\mathrm{a}_{30}$ heritability increased substantially (0.39). Unfortunately, neither genetic correlations between different traits nor rank correlations between bulls were reported. Moreover, estimates based on daughter distributions sometimes vary greatly from sire to sire (Figure 8) because inclusion of NC samples in analysis creates a bimodal distribution, as outlined by Tyrisevä et al. (2008).

At this point, we might ask whether it is correct to assign a value of zero to $\mathrm{a}_{30}$ of NC samples. Should samples that coagulate after $1 \mathrm{~min}, 1 \mathrm{~h}$, or never have the same value? How can NC samples have RCT values? An answer to this last question has been provided by
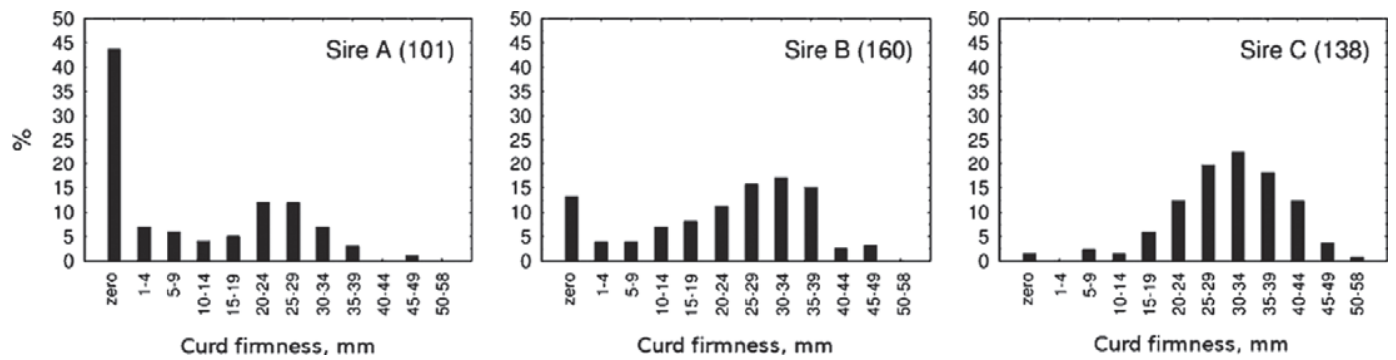

Figure 8. Distribution (\%) of curd firmness of milk samples of the daughters of 3 Finnish Ayrshire AI sires differing in their genetic merit for curd firmness. The "zero" value refers to samples that did not coagulate within 30 min of enzyme addition. The number of daughters is provided in parentheses (Tyrisevä et al., 2008). 
Table 11. Comparison among 4 statistical models ${ }^{1}$ for the estimates of genetic parameters of rennet coagulation time (RCT) using individual samples of 1,025 Holstein-Friesian cows simulating a duration of observation period of 31 or 18 min (Cecchinato and Carnier, 2011) ${ }^{2}$

\begin{tabular}{|c|c|c|c|c|c|c|c|c|}
\hline$\sigma_{H}^{2}$ & 3.4 & 7.3 & 0.22 & 0.30 & 0.6 & 4.0 & 0.36 & 0.33 \\
\hline$\sigma_{E}^{2}$ & 12.9 & 26.0 & 1.00 & 1.00 & 3.8 & 9.5 & 1.00 & 1.00 \\
\hline $\begin{array}{l}h^{2} \\
\text { Between-method }^{4}\end{array}$ & 0.23 & 0.23 & 0.11 & 0.12 & 0.20 & 0.25 & 0.11 & 0.12 \\
\hline $\begin{array}{l}\text { Within-method }{ }^{4} \\
\quad(31 \text { min vs. } 18 \mathrm{~min})\end{array}$ & & & & & 0.60 & 0.88 & 0.84 & 0.52 \\
\hline
\end{tabular}

${ }^{1}$ Linear $=$ standard Gaussian linear animal model for the analysis of RCT of coagulated milk samples at 31 and 18 min; Censored $=$ rightcensored Gaussian linear animal model for the analysis of RCT of coagulated and noncoagulated (censored) milk samples at 31 and 18 min; Survival = survival sire model for the analysis of RCT of coagulated and noncoagulated milk samples at 31 and 18 min; Threshold $=$ threshold sire model for the analysis of RCT as a binary trait (i.e., milk coagulation occurrence at 31 and 18 min).

${ }^{2}$ All estimates are presented as median of the marginal posterior density of the parameter.

${ }^{3} \sigma_{A}^{2}=$ additive genetic variance; $\sigma_{H}^{2}=$ herd variance; $\sigma_{E}^{2}=$ residual variance.

${ }^{4}$ Spearman correlations for sire rankings.

Cecchinato and Carnier (2011), who analyzed a large data set of RCT values from Holstein-Friesian cows using 4 different statistical models. These included a classical linear animal model analyzing only coagulating samples, a right-censored linear animal model using data on all samples (NC samples were considered censored), a survival (sire) model (NC samples were considered not yet coagulated at the end of observation period), and a threshold (sire) model (involving categorization of $\mathrm{RCT}$ on a binary scale). The main results are summarized in Table 11 and show that the censored model yielded variance estimates that were about twice those obtained with the linear model. However, the heritability estimates obtained using the 2 models were very similar. The survival and threshold models yielded similar estimates of additive genetic variance, expressed as a fraction of error variance. This meant that the heritability values afforded by the 2 models were similar, being about half those of the other models. The rank correlations of sire breeding values were high (but did not approach unity) with the exception of the very low rank correlation evident between sire breeding values obtained using the linear and threshold models.

Examining the same data set, and assuming that the duration of the coagulation test was only $18 \mathrm{~min}$, all samples coagulating after $18 \mathrm{~min}$ would have been treated as NC; the NC samples thus constituted about $50 \%$ of all samples. Even although all variances calculated using the linear and censored linear models were much lower than those estimated using the original data set, the heritability estimates remained almost unchanged, regardless of the model used, as was also the case when rank correlations were examined (Table 11). An indirect measure of estimate validation may be obtained by computing the rank correlations of sire breeding values estimated using each model, using both the original and the reduced data set, followed by comparison of the output data. The results show that the rankings yielded by the right-censored linear animal and the survival (sire) model were more stable than those obtained using the linear animal and the threshold (sire) model. Use of a right-censored linear animal model may be preferable when a significant number of NC samples must be accommodated in analysis.

\section{Modeling of Curd Firming and Syneresis}

As outlined above, the major limitations of traditional MCP are (1) the existence of NC samples, (2) the high proportion of samples for which $\mathrm{k}_{20}$ is unavailable, and (3) the dependence of $\mathrm{a}_{30}$ information on the RCT value (Bittante, 2011). In the case of NC samples, it is impossible to estimate $\mathrm{RCT}, \mathrm{k}_{20}$, or $\mathrm{a}_{30}$. This problem is of increasing importance because the Holstein-Friesian has become the leading breed worldwide and yields a higher proportion of $\mathrm{NC}$ samples compared with other dairy breeds (some northern European breeds excluded). Further, $\mathrm{k}_{20}$ cannot be determined for late-coagulating samples because the long RCT does not permit attainment of a $20-\mathrm{mm}$ oscillation interval within 30 min. The increasing proportion of slowly coagulating 

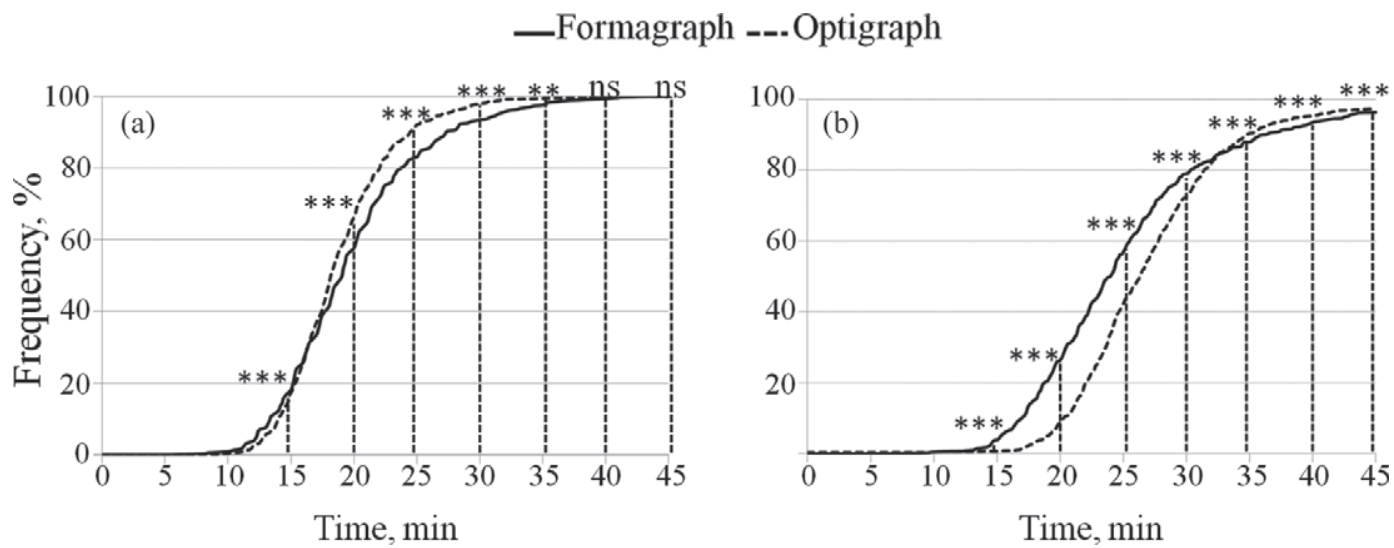

Figure 9. Cumulative frequency (a) of coagulating samples and (b) of samples with a $\mathrm{k}_{20}$ value, according to the time interval from rennet addition and to the instrument used (Cipolat-Gotet et al., 2012). Formagraph from Foss Electric A/S (Hillerød, Denmark); Optigraph from Ysebaert SA (Frépillon, France). ${ }^{* *} P<0.01 ;{ }^{* * *} P<0.001$.

milk samples makes $\mathrm{k}_{20}$ data increasingly desirable in the dairy industry $\left(\mathrm{k}_{20}\right.$ indicates the optimal time for curd cutting), but it is almost impossible to measure this trait in late-coagulating samples. Finally, as explained, $\mathrm{a}_{30}$ is often highly dependent on RCT, both phenotypically and genetically. This is especially the case when milk from slowly coagulating herds or breeds is analyzed. Under such circumstances, $\mathrm{a}_{30}$ does not afford any significant information not already provided by RCT.

Several studies have modeled the dynamics of milk curdling using different rheometers (Douillard, 1973, 1986; Gervais and Cerf, 1983; McMahon et al., 1984; Dejmek, 1987; O'Callaghan and Guinee, 1996; Esteve et al., 2001). Technical improvements in the Formagraph and the introduction of the CRM (Polo Trade) maintained the principles of the test but now store, and afford ready access to, information obtained at any time during coagulation, instead of using only 3 points of information (Figure 3).

Recently, Bittante (2011) exploited all available Formagraph data to appropriately model curd firming over time $\left(\mathrm{CF}_{\mathrm{t}}\right)$. New parameters relevant to coagulation were derived, with the aim of using all available information to yield parameters that were more informative than the traditional MCP.

The derived model contained 3 parameters: $\mathrm{CF}_{\mathrm{t}}=$ $\mathrm{CF}_{\mathrm{P}} \times\left[1-\mathrm{e}_{\mathrm{CF}}^{-\mathrm{k}} \times(\mathrm{t}-\mathrm{RCT})\right]$, where $\mathrm{CF}_{\mathrm{P}}(\mathrm{mm})$ is the potential asymptotical $\mathrm{CF}$ at an infinite time and $\mathrm{k}_{\mathrm{CF}}$ $\left(\mathrm{min}^{-1}\right)$ is the curd-firming rate constant. The 3 novel parameters are less interdependent than traditional MCP when used to assess various milk samples, but the practical and scientific utility of the parameters and any relationship between the parameters and genetic features require further study. Moreover, traditional
MCP can be estimated by the model, using all information available, not only data from 3 time points; instrumental repeatability appeared to increase slightly when this approach was taken. Finally, $\mathrm{k}_{20}$ values for samples that coagulate very late, or that form curd very slowly, can be computed using the model (Bittante, 2011).

The modeling of data obtained during the 30-min testing time can help to address certain limitations of traditional MCP but cannot solve the problems posed by NC samples or yield insight into syneresis, as shown by comparing data obtained from milk samples of different species (Figure 4). These problems can be addressed by prolonging the lactodynamographic test period beyond 30 min. Cipolat-Gotet et al. (2012) observed that almost all milk samples coagulate within 90 min. Thus, we could postulate that $\mathrm{NC}$ milk does not exist and that it is more correct to refer to late-coagulating milk. Moreover, prolongation of the observation time allows $\mathrm{k}_{20}$ values to be computed for all samples for which $\mathrm{CF}_{\mathrm{P}}$ is $<20 \mathrm{~mm}$ (Figure 9). A good compromise between the need to gather information and the need to save time would be prolongation of the observation period to 45 to 60 min, depending on the breed studied and the aim of the analysis.

In milk of all species (Figure 4), CF initially increases to a maximum value and then tends to decrease, mainly because of syneresis (expulsion of whey from curd). The 3-parameter model of Bittante (2011) does not fit observations in the descending part of the diagram. Bittante et al. (G. Bittante, B. Contiero, and A. Cecchinato, University of Padova, Legnaro, Italy, unpublished data) thus developed a 4-parameter model to fit the observed data: $\mathrm{CF}_{\mathrm{t}}=\mathrm{CF}_{\mathrm{P}} \times\left[1-\mathrm{e}_{\mathrm{CF}}^{-\mathrm{k}} \times(\mathrm{t}-\mathrm{RCT})\right] \times\left[\mathrm{e}^{-\mathrm{k}}{ }_{\mathrm{SR}} \times(\mathrm{t}-\right.$ ${ }_{\mathrm{RCT})}$. In this model, the fourth parameter, $\mathrm{k}_{\mathrm{SR}}\left(\mathrm{min}^{-1}\right)$ is the curd syneresis rate constant, which models the 


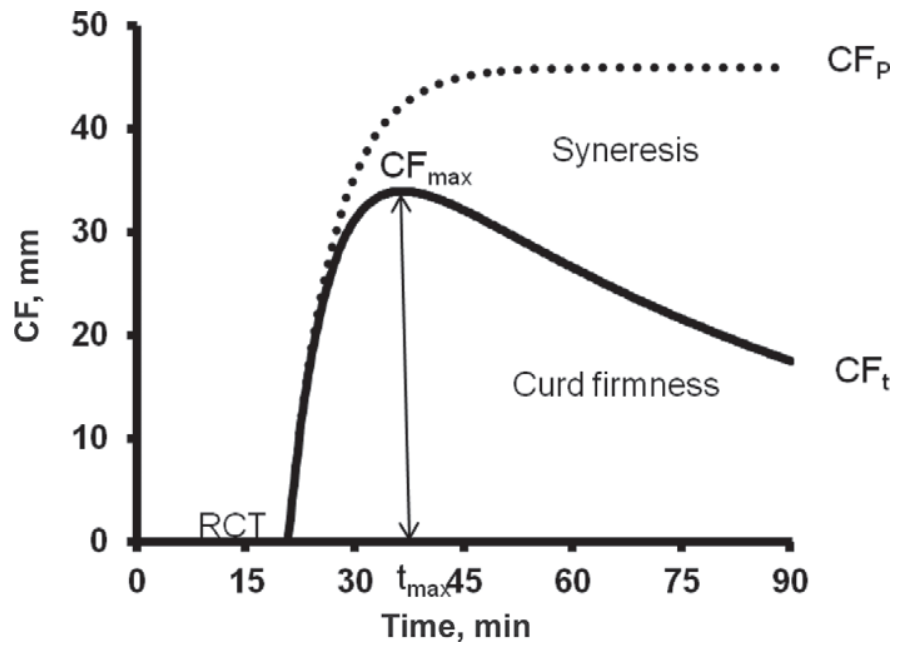

Figure 10. Modeling prolonged observations of curd firmness (CF) at time $\mathrm{t}\left(\mathrm{CF}_{\mathrm{t}}\right)$ and quantification of syneresis process $(\mathrm{RCT}=$ rennet coagulation time; $\mathrm{CF}_{\mathrm{P}}=$ potential asymptotical $\mathrm{CF}$ in absence of syneresis; $\mathrm{CF}_{\max }=$ maximum $\mathrm{CF}_{\mathrm{t}}$ value; $\mathrm{t}_{\max }=$ time at $\left.\mathrm{CF}_{\max }\right)$.

curve in the declining region. According to this model, the $\mathrm{CF}$ of any coagulated sample is a function of the maximum asymptotical $\mathrm{CF}\left(\mathrm{CF}_{\mathrm{P}}\right)$ and the 2 opposing phenomena of curd firming and syneresis, represented by appropriate rate constants. As curd firming is much more rapid than syneresis, the result is an increase of $\mathrm{CF}$ to a maximum $\left(\mathrm{CF}_{\max }\right)$ followed by a decreasing phase during which $\mathrm{CF}$ tends asymptotically to zero (Figure 10). Application of this model permits estimation of the 4 parameters, and also allows estimation of traditional $\mathrm{MCP}, \mathrm{CF}_{\max }$, and the time at which $\mathrm{CF}_{\max }$ is attained $\left(t_{\max }\right)$. The practical value of the proposed model requires study, as does any genetic basis of the novel parameters.

\section{Use of Optical Lactodynamography Versus Mechanical Instruments}

Recently, both near-infrared reflectance spectroscopy (NIRS) and other optical methods have been used to monitor coagulation, curd firming, and syneresis during laboratory-based cheese-making (Laporte et al., 1998; O'Callaghan et al., 2002; Fagan et al., 2007a). Nearinfrared reflectance spectroscopy has also been used to monitor coagulation and curd firming in association with a lactodynamographic approach. The Optigraph (Ysebaert SA, Frépillon, France) uses a single NIR wavelength to monitor coagulation. This device estimates MCP by analyzing optical information acquired in real time; the optical values are transformed to simulate traditional parameters. A direct comparison between mechanical and optical techniques (Kübarsepp et al., 2005 ) has revealed that RCT values from the 2 instruments are similar, whereas $\mathrm{a}_{30}$ values are quite different. Similar results have been reported by Cipolat-Gotet et al. (2012) on a large data set. Cecchinato et al. (2011a) estimated genetic parameters for MCP obtained from the 2 instruments (Formagraph and Optigraph; Table 12). The genetic correlations between the measures determined with the 2 lactodynamographs were high for all MCP, particularly for RCT. The Optigraph can also record all data yielded by lactodynamographic analysis (the measure occurs every $6 \mathrm{~s}$ ) and can refer to the 3-parameter model proposed by Bittante (2011). The Optigraph also makes possible the prolongation of the observation period; the curve shape yielded by the instrument is similar to that upon application of the 4-parameter model. However, Optigraph data are somewhat erratic; inappropriate negative values can appear. It is likely that the software has been optimized

Table 12. Comparison between a computerized mechanical instrument (Formagraph, Foss, Hillerød, Denmark) and a computerized optical instrument (Optigraph, Ysebaert SA, Frépillon, France) in terms of variance components and heritability estimates of milk coagulation properties (MCP) analyzed with both instruments on 913 individual milk samples of Brown Swiss cows, and phenotypic $\left(\mathrm{r}_{\mathrm{P}}\right)$ and genetic $\left(\mathrm{r}_{\mathrm{A}}\right)$ correlations between the MCP analyzed by the 2 instruments treated as different traits (Cecchinato et al., 2011a) ${ }^{1}$

\begin{tabular}{|c|c|c|c|c|c|c|}
\hline Item $^{2}$ & \multicolumn{2}{|c|}{$\mathrm{RCT}, \min$} & \multicolumn{2}{|c|}{$\mathrm{k}_{20}, \min$} & \multicolumn{2}{|c|}{$\mathrm{a}_{30}, \mathrm{~mm}$} \\
\hline \multicolumn{7}{|l|}{$\begin{array}{l}\text { Average value } \\
\text { Heritability estimates }\end{array}$} \\
\hline$\sigma_{A}^{2}$ & 7.1 & 4.2 & 2.1 & 3.1 & 21.0 & 23.8 \\
\hline$\sigma_{H}^{2}$ & 4.3 & 2.1 & 0.3 & 0.4 & 6.4 & 10.5 \\
\hline Correlations between instruments & & & & & & \\
\hline$r_{P}$ & \multicolumn{2}{|c|}{0.81} & \multicolumn{2}{|c|}{0.52} & \multicolumn{2}{|c|}{0.73} \\
\hline $\mathrm{r}_{\mathrm{A}}$ & \multicolumn{2}{|c|}{0.97} & \multicolumn{2}{|c|}{0.76} & \multicolumn{2}{|c|}{0.92} \\
\hline
\end{tabular}

${ }^{1} \mathrm{RCT}$ - rennet coagulation time; $\mathrm{k}_{20}=$ curd-firming time; $\mathrm{a}_{30}=$ curd firmness.

${ }^{2} \sigma_{A}^{2}=$ additive genetic variance; $\sigma_{H}^{2}=$ herd variance; $\sigma_{E}^{2}=$ residual variance. 
Table 13. Genetic parameters of milk coagulation properties (RCT, rennet coagulation time; $\mathrm{a}_{30}$, curd firmness) measured by computerized renneting meter (CRM) or predicted by mid-infrared reflectance spectroscopy (MIRS) on individual milk samples of 1,200 Brown Swiss cows (Cecchinato et al., 2009)

\begin{tabular}{|c|c|c|c|c|}
\hline \multirow[b]{2}{*}{ Genetic parameter $^{1}$} & \multicolumn{2}{|c|}{$\mathrm{RCT},{ }^{2} \min$} & \multicolumn{2}{|c|}{$\mathrm{a}_{30}, \mathrm{~mm}$} \\
\hline & CRM & MIRS & CRM & MIRS \\
\hline $\mathrm{R}^{2}$ of calibration & - & 63.8 & - & 49.0 \\
\hline$\sigma_{A}^{2}$ & 4.9 & 3.7 & 18.9 & 17.1 \\
\hline$\sigma_{H}^{2}$ & 1.7 & 1.5 & 9.4 & 5.3 \\
\hline$\sigma_{E}^{2}$ & 8.5 & 4.6 & 50.7 & 20.0 \\
\hline$h^{2}$ & 0.32 & 0.37 & 0.24 & 0.39 \\
\hline Correlations & & & & \\
\hline $\mathrm{r}_{\mathrm{P}}$ & \multicolumn{2}{|c|}{0.67} & \multicolumn{2}{|c|}{0.51} \\
\hline $\mathrm{r}_{\mathrm{A}}$ & \multicolumn{2}{|c|}{0.93} & \multicolumn{2}{|c|}{0.77} \\
\hline
\end{tabular}

to mimic a traditional lactodynamographic output up to $30 \mathrm{~min}$, and fine-tuning is required if the observation period is to be extended beyond $30 \mathrm{~min}$.

In summary, the use of optical instruments is promising, but their outputs require improvement in terms of repeatability and practical significance, especially if the recording period is prolonged beyond $30 \mathrm{~min}$. However, genetic correlations between measurements of traditional MCP measured by the 2 technologies are high; either data set can be used in genetic improvement programs. Unfortunately, measurements obtained using either type of instrument are time consuming if large populations are to be studied; such work is currently unfeasible.

\section{MIRS Optical Techniques}

The utility of optical technologies is not limited to mechanical measurement of MCP by lactodynamographic tests, but rather includes prediction of MCP from untreated milk. For this use, it is not necessary to induce coagulation. Dal Zotto et al. (2008) explored whether mid-infrared reflectance spectroscopy (MIRS) could be used to indirectly predict the MCP of fresh milk, using appropriate calibration algorithms. The results indicated that $\mathrm{RCT}$ of fresh milk and of milk refrigerated (with preservative) for up to $8 \mathrm{~d}$ could be predicted by MIRS. The degree of precision was moderate, because the coefficients of determination of crossvalidation ranged from 0.55 to 0.73 . Neither the RCT of frozen samples nor the $\mathrm{a}_{30}$ of samples stored under different conditions could be predicted using MIRS; the coefficients of determination of cross-validation were $<0.45$. In a subsequent report, De Marchi et al. (2009), using a larger data set and mathematical pretreatment of spectra, obtained similar results when both MCP were calculated. The authors also found that $\mathrm{pH}$ and titratable acidity could be predicted with a precision similar to that of RCT.

Cecchinato et al. (2009) compared MCP measured using CRM (Polo Trade) with those predicted by MIRS, and estimated genetic parameters of measured and predicted MCP. As expected, all variance components of predicted MCP were lower than those of measured traits but to different extents (Table 13). For RCT, the additive genetic variance was reduced by $24 \%$, the herd variance by $12 \%$, and the error variance by $46 \%$; consequently, heritability changed slightly from $32 \%$ (obtained using measured traits) to $37 \%$ (calculated using predicted traits). For $\mathrm{a}_{30}$, the additive genetic variance was reduced by only $10 \%$, whereas the herd and error variances were reduced by 44 and $61 \%$, respectively. As a result, heritability changed from $24 \%$ (measured) to $39 \%$ (predicted). The relationships between measured and predicted MCP were even more interesting. Although the phenotypic correlations were moderate $(67$ and $51 \%$ for $\mathrm{RCT}$ and $\mathrm{a}_{30}$, respectively), the genetic correlations attained levels of $93 \%$ for RCT and $77 \%$ for $\mathrm{a}_{30}$.

In summary, although the predictive value remains only moderate, MIRS could be used at the population level to efficiently achieve genetic improvements in MCP. Moreover, such outcomes could be attained without the use of additional labor and at the cost of spectrometric calibration. This is because the required predictions can be obtained using the same samples and instruments that are currently used in milk fat and protein analyses during current milk recording (Barbano and Lynch, 2006). 
Table 14. Summary of relative importance of the main common and individual genetic and environmental factors on phenotype of cows for milk coagulation properties (MCP: RCT, rennet coagulation time; $\mathrm{a}_{30}$, curd firmness) and for some other important groups of milk traits (yield $=$ milk, fat, and protein production; content $=$ milk content of fat, protein, and casein; acidity $=\mathrm{pH}$ and titratable acidity of milk; mastitis $=$ SCS and other mastitis traits) and relationships among them

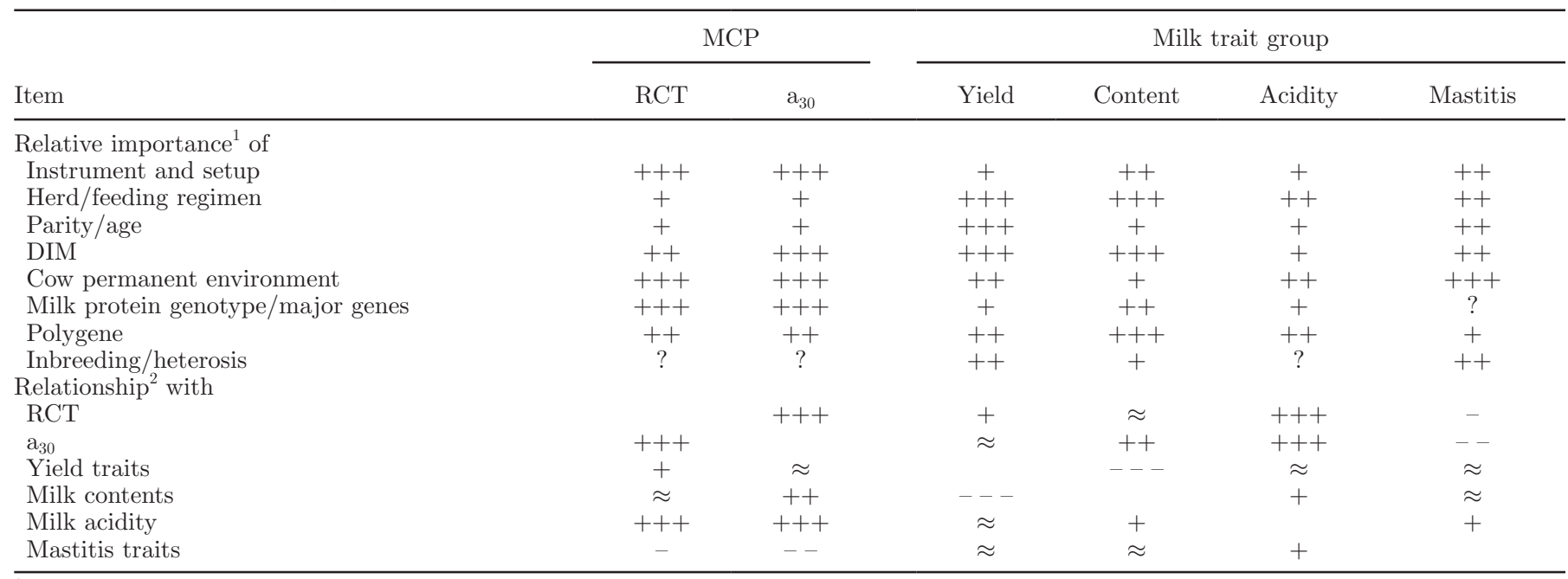

${ }^{1}$ Importance: $+++=$ high; $++=$ medium; $+=$ low; $?=$ unknown.

${ }^{2}$ Relationship: $+++=$ high favorable $++=$ medium favorable; $+=$ low favorable $;---=$ high unfavorable; $--=$ medium unfavorable; $-=$ low unfavorable; $\approx=$ unrelated or contradictory results.

\section{Conclusion: Improving MCP at the Population Level}

In conclusion, MCP are economically important in the dairy industry, particularly for PDO cheeses. Milk coagulation properties vary greatly among ruminant species (cattle, buffalo, sheep, and goats), among breeds within species, and among individuals. Variations occur in coagulation time, extent of curd firming, and development of syneresis. Cattle breeds are characterized by large variations in coagulation ability; the milk of cows from breeds originating in centralsouthern Europe is generally more valuable in terms of cheesemaking (exhibiting earlier coagulation and higher curd firmness) than milk from breeds that originated in central-northern Europe, notably the Holstein-Friesian and Scandinavian Red breeds.

The relative importance of the source of variations in MCP may be summarized as follows (Table 14):

- MCP are heavily influenced by instrument of analysis (mechanical vs. optical) and operational setup (type and concentration of rennet, milk temperature, and $\mathrm{pH}$ ). This makes comparisons among different studies, laboratories, and approaches very difficult.

- MCP are influenced by herd, but this influence is much lower than that exerted on other milk traits (yield, contents, acidity, and mammary health). This means that housing facilities, nutrition, hygiene, and herd management modify the coagulation properties of milk to only a limited extent.
- MCP are not strongly influenced by either cow age or parity, and data obtained from different lactations of the same animal can be combined.

- MCP are much more influenced by lactation stage of the cow and, like milk yield and contents, require proper modeling.

- MCP are heavily influenced by the permanent environment of a cow; individual repeatability is high and there is no need to frequently sample a cow to characterize MCP of her milk.

- MCP are heavily influenced by variations in major genes; this is especially true for genetic variants of $\kappa$-casein. However, such genetic influences explain only part of the observed genetic variance.

- MCP of cattle are also influenced by polygenic variation. In a narrow sense, heritability is moderate. In a broad sense, however, heritability (including the effects of major genes) is high and comparable to that of other milk quality traits.

- MCP have not been well studied in terms of possible influences of inbreeding and heterosis, and current efforts toward this end are needed.

The results of earlier studies have contributed to a better understanding of genetic correlations among different traits. In particular, (1) RCT and $\mathrm{a}_{30}$ values are strictly correlated, meaning that measurement of the latter trait adds but little to the information afforded by the first; (2) RCT is heavily influenced by $\mathrm{pH}$ and titratable acidity of milk; and (3) $\mathrm{a}_{30}$ is greatly affected by milk acidity and, to a lower extent, by milk quality, 
particularly casein content. Curd firmness is unfavorably influenced by SCS and other indicators of mastitis.

Milk coagulation properties are very useful for the dairy industry and are heritable. Attainment of genetic improvements in MCP at the population level appears to be daunting because the required analytical steps are expensive and time consuming (albeit reliable). In individual breeds, indirect selection could exploit measures of $\mathrm{pH}$ or titratable acidity and, if enhanced curd firmness is desired, of casein content.

Selection of genetic variants expressing different levels of milk proteins, especially $\kappa$-casein, will be valuable if coagulation ability within a population is to be improved; this is true even though current relevant data are sparse. Recent works have identified other genes exerting major influences on MCP and genome-wide association studies are appearing.

The use of traditional MCP is not possible in the presence of $\mathrm{NC}$ or late-coagulating milk, because RCT, $\mathrm{k}_{20}$, and $\mathrm{a}_{30}$ are not measurable in the first case, and $\mathrm{k}_{20}$ is not measureable in the latter. Thus, in the absence of appropriate statistical evaluation, genetic parameters and estimates of breeding value cannot be obtained or may be biased.

The use of MIRS to predict RCT and $\mathrm{a}_{30}$ in the milk recording system may afford a useful and reliable means wherein MCP can be evaluated at the population level at minimal cost. No additional sampling is required, and no novel analysis is needed. Mid-infrared reflectance spectroscopy devices simply require calibration to allow predictions of MCP from spectra already used for the prediction of fat and protein contents.

Finally, both the cheese industry and associations involved in animal selection may be assisted, by the advances described herein, in resolving several problems associated with traditional MCP determination. Useful data may be achieved upon prolongation of the lactodynamographic testing period, via appropriate modeling of MCP. These approaches, which also provide information on syneresis, should be further investigated at both the phenotypic and genetic levels.

\section{ACKNOWLEDGMENTS}

The authors thank the Autonomous Province of Trento (Italy) for funding.

\section{REFERENCES}

Aaltonen, M.-L., and V. Antila. 1987. Milk renneting properties and the genetic variants of proteins. Milchwissenschaft 42:490-492.

Aleandri, R., J. C. Schneider, and L. G. Buttazzoni. 1989. Evaluation of milk for cheese production based on milk characteristics and Formagraph measures. J. Dairy Sci. 72:1967-1975.
Alipanah, M., and L. A. Kalashnikova. 2007. Influence of $\kappa$-casein genetic variant on cheese making ability. J. Anim. Vet. Adv. 6:855-857.

Amigo, L., P. J. Martin-Alvarez, E. Garcia-Muro, and I. Zarazaga. 2001. Effect of milk protein haplotypes on the composition and technological properties of Fleckvieh bovine milk. Milchwissenschaft 56:488-491.

Annibaldi, S., F. Ferri, and R. Morra. 1977. Nuovi orientamenti nella valutazione tecnica del latte: Tipizzazione lattodinamografica. Sci. Tecn. Latt. Cas. 28:115-126.

Ariota, B., G. Campanile, A. Potena, R. Napolano, B. Gasparrini, G. L. Neglia, and R. Di Palo. 2007. Ca and P in buffalo milk: Curd yield and milk clotting parameters. Ital. J. Anim. Sci. 6(Suppl. 1):497-499.

Auldist, M. J., K. A. Johnston, N. J. White, W. P. Fitzsimons, and M. J. Boland. 2004. A comparison of the composition, coagulation characteristics and cheesemaking capacity of milk from Friesian and Jersey dairy cows. J. Dairy Res. 71:51-57.

Auldist, M. J., C. Mullins, B. O'Brien, B. T. O'Kennedy, and T. Guinee. 2002. Effect of cow breed on milk coagulation properties. Milchwissenschaft 57:140-143.

Banos, G., J. A. Woolliams, B. W. Woodward, A. B. Forbes, and M. P. Coffey. 2008. Impact of single nucleotide polymorphisms in leptin, leptin receptor, growth hormone receptor, and diacylglycerol acyltransferase (DGAT1) gene loci on milk production, feed, and body energy traits of UK dairy cows. J. Dairy Sci. 91:3190-3200.

Barbano, D. M., and J. M. Lynch. 2006. Major advances in testing of dairy products: Milk component and dairy product attribute testing. J. Dairy Sci. 89:1189-1194.

Barber, D. G., A. V. Houlthan, F. C. Lynch, and D. P. Poppt. 2005 The influence of nutrition, genotype and stage of lactation on milk casein composition. Pages 203-216 in Indicators of Milk and Beef Quality. J. F. Hocquette and S. Gigli, ed. EAAP publication 112. Wageningen Academic Publishers, Wageningen, the Netherlands.

Barłowska, J., Z. Litwińczuk, A. Wolanciuk, and A. Brodziak. 2009 Relationship of somatic cell count to daily yield and technological usefulness of milk from different breeds of cows. Pol. J. Vet. Sci. 12:75-79.

Barłowska, J., M. Szwajkowska, Z. Litwińczuk, and J. Król. 2011. Nutritional value and technological suitability of milk from various animal species used for dairy production. Comp. Rev. Food Sci. Food Saf. 10:291-302.

Bartocci, S., and S. Terramoccia. 2010. Variations in the production, qualitative characteristics and coagulation parameters of the milk of the riverine buffalo determined by the energy/protein content of the diet. Asian-australas. J. Anim. Sci. 23:1166-1173.

Bartocci, S., C. Tripaldi, and S. Terramoccia. 2002. Characteristics of foodstuffs and diets, and the quanti-qualitative milk parameters of Mediterranean buffaloes bred in Italy using the intensive system. An estimate of the nutritional requirements of buffalo herds lactating or dry. Livest. Prod. Sci. 77:45-58.

Bastian, E. D., R. J. Brown, and C. A. Ernstrom. 1991. Plasmin activity and milk coagulation. J. Dairy Sci. 74:3677-3685.

Bencini, R. 2002. Factors affecting the clotting properties of sheep milk. J. Sci. Food Agric. 82:705-719.

Bertoni, G., L. Calamari, M. G. Maianti, and B. Battistotti. 2005 Milk for Protected Denomination of Origin (PDO) cheeses: I. The main required features. Pages 217-228 in Indicators of Milk and Beef Quality. J. F. Hocquette and S. Gigli, ed. EAAP Publication 112. Wageningen Academic Publishers, Wageningen, the Netherlands.

Bittante, G. 2011. Modeling rennet coagulation time and curd firmness of milk. J. Dairy Sci. 94:5821-5832.

Bittante, G., A. Cecchinato, N. Cologna, M. Penasa, F. Tiezzi, and M. De Marchi. 2011a. Factors affecting the incidence of first-quality wheels of Trentingrana cheese. J. Dairy Sci. 94:3700-3707.

Bittante, G., N. Cologna, A. Cecchinato, M. De Marchi, M. Penasa, F. Tiezzi, I. Endrizzi, and F. Gasperi. 2011b. Monitoring of sensory attributes used in the quality payment system of Trentingrana cheese. J. Dairy Sci. 94:5699-5709. 
Bittante, G., M. Marusi, F. Cesarini, M. Povinelli, and M. Cassandro. 2002. Genetic analysis on milk rennet-coagulation ability in Italian Holstein cows. CD-ROM commun. No. 09-03 in Proc. 7th World Congr. Genet. Appl. Livest. Prod., Montpellier, France.

Boettcher, P. J., A. Caroli, A. Stella, S. Chessa, E. Budelli, F. Canavesi, S. Ghiroldi, and G. Pagnacco. 2004. Effects of casein haplotypes on milk production traits in Italian Holstein and Brown Swiss cattle. J. Dairy Sci. 87:4311-4317.

Bonfatti, V., A. Cecchinato, L. Gallo, A. Blasco, and P. Carnier. 2011. Genetic analysis of detailed milk protein composition and coagulation properties in Simmental cattle. J. Dairy Sci. 94:5183-5193.

Bonfatti, V., G. Di Martino, A. Cecchinato, L. Degano, and P. Carnier. 2010. Effects of $\beta$ - $\kappa$-casein (CSN2-CSN3) haplotypes, $\beta$-lactoglobulin (BLG) genotypes, and detailed protein composition on coagulation properties of individual milk of Simmental cows. J. Dairy Sci. 93:3809-3817.

Buchberger, J., and P. Dovč. 2000. Lactoprotein genetic variants in cattle and cheese making ability. Food Technol. Biotechnol. 38:91-98.

Bynum, D. G., and N. F. Olson. 1982a. Standardization of a device to measure firmness of curd during clotting of milk. J. Dairy Sci. 65:1321-1324.

Bynum, D. G., and N. F. Olson. 1982b. Influence of curd firmness at cutting on Cheddar cheese yield and recovery of milk constituents. J. Dairy Sci. 65:2281-2290.

Calamari, L., G. Bertoni, M. G. Maianti, and B. Battistotti. 2005. Milk for Protected Denomination of Origin (PDO) cheeses: II. The evaluation techniques of milk suitability. Pages 229-244 in Indicators of Milk and Beef Quality. J. F. Hocquette and S. Gigli, ed. EAAP Publication 112. Wageningen Academic Publishers, Wageningen, the Netherlands.

Calvo, M. M., and E. Balcones. 2000. Some factors influencing the syneresis of bovine, ovine and caprine milks. J. Dairy Sci. 83:17331739.

Caroli, A. M., S. Chessa, and G. J. Erhardt. 2009. Invited review: Milk protein polymorphism in cattle: Effect on animal breeding and human nutrition. J. Dairy Sci. 92:5335-5352.

Cassandro, M., A. Comin, M. Ojala, R. Dal Zotto, M. De Marchi, L. Gallo, P. Carnier, and G. Bittante. 2008. Genetic parameters of milk coagulation properties and their relationships with milk yield and quality traits in Italian Holstein cows. J. Dairy Sci. 91:371-376.

Cecchinato, A., and P. Carnier. 2011. Short communication: Statistical models for the analysis of coagulation traits using coagulating and non-coagulating milk information. J. Dairy Sci. 94:4214-4219.

Cecchinato, A., M. De Marchi, L. Gallo, G. Bittante, and P. Carnier. 2009. Mid-infrared spectroscopy predictions as indicator traits in breeding programs for enhanced coagulation properties of milk. J. Dairy Sci. 92:5304-5313.

Cecchinato, A., M. Penasa, C. Cipolat Gotet, M. De Marchi, and G. Bittante. 2012a. Short communication: Factors affecting coagulation properties of Mediterranean buffalo milk. J. Dairy Sci. 95:1709-1713.

Cecchinato, A., M. Penasa, M. De Marchi, C. Cipolat Gotet, I. Bazzoli, N. Cologna, and G. Bittante. 2011a. Methods for the assessment of milk coagulation properties: A genetic analysis. J. Dairy Sci. 89(E-Suppl. 1):705. (Abstr.)

Cecchinato, A., M. Penasa, M. De Marchi, L. Gallo, G. Bittante, and P. Carnier. 2011b. Genetic parameters of coagulation properties, milk yield, quality, and acidity estimated using coagulating and noncoagulating milk information in Brown Swiss and HolsteinFriesian cows. J. Dairy Sci. 94:4205-4213.

Cecchinato, A., C. Ribeca, A. Maurmayr, M. Penasa, M. De Marchi, N. P. P. Macciotta, M. Mele, P. Secchiari, G. Pagnacco, and G. Bittante. 2012b. Short communication: Effects of $\beta$-lactoglobulin, stearoyl-coenzyme A desaturase 1 , and sterol regulatory element binding protein gene allelic variants on milk production, composition, acidity and coagulation properties of Brown Swiss cows. J. Dairy Sci. 95:450-454.

Cecchinato, A., C. Ribeca, M. Penasa, C. Cipolat-Gotet, M. De Marchi, A. Maurmayr, and G. Bittante. 2012c. Associations between single nucleotide polymorphisms in multiple candidate genes on milk yield, composition, coagulation properties and individual cheese yield in Brown Swiss cows. J. Dairy Sci. 95(E-Suppl.):402. (Abstr.)

Chiofalo, V., R. Maldonato, B. Martin, D. Dupoint, and J.-B. Coulon. 2000. Chemical composition and coagulation properties of Modicana and Holstein cow's milk. INRA. EDP Sci. Ann. Zootech. 49:497-503.

Cipolat-Gotet, C., A. Cecchinato, M. De Marchi, M. Penasa, and G. Bittante. 2012. Comparison between mechanical and near-infrared methods for assessing coagulation properties of bovine milk. J. Dairy Sci. 95:6806-6819. http://dx.doi.org/10.3168/jds.20125551.

Comin, A., M. Cassandro, S. Chessa, M. Ojala, R. Dal Zotto, M. De Marchi, P. Carnier, L. Gallo, G. Pagnacco, and G. Bittante. 2008. Effects of composite $\beta$ - and $\kappa$-casein genotypes on milk coagulation, quality, and yield traits in Italian Holstein cows. J. Dairy Sci. 91:4022-4027.

Comin, A., M. Cassandro, M. Povinelli, and G. Bittante. 2005. Genetic aspects of milk coagulation properties in Italian Holstein cows. Ital. J. Anim. Sci. 4(Suppl. 2):10-12.

Dal Zotto, R., M. De Marchi, A. Cecchinato, M. Penasa, M. Cassandro, P. Carnier, L. Gallo, and G. Bittante. 2008. Reproducibility and repeatability of measures of milk coagulation properties and predictive ability of mid-infrared reflectance spectroscopy. J. Dairy Sci. 91:4103-4112.

Davoli, R., S. Dall'Olio, and V. Russo. 1990. Effect of $\kappa$-casein genotype on the coagulation properties of milk. J. Anim. Breed. Genet. 107:458-464

De Marchi, M., G. Bittante, R. Dal Zotto, C. Dalvit, and M. Cassandro. 2008. Effect of Holstein Friesian and Brown Swiss breeds on quality of milk and cheese. J. Dairy Sci. 91:4092-4102.

De Marchi, M., R. Dal Zotto, M. Cassandro, and G. Bittante. 2007. Milk coagulation ability of five dairy cattle breeds. J. Dairy Sci. 90:3986-3992.

De Marchi, M., C. C. Fagan, C. P. O'Donnell, A. Cecchinato, R. Dal Zotto, M. Cassandro, M. Penasa, and G. Bittante. 2009. Prediction of coagulation properties, titratable acidity, and $\mathrm{pH}$ of bovine milk using mid-infrared spectroscopy. J. Dairy Sci. 92:423-432.

Dejmek, P. 1987. Dynamic rheology of rennet curd. J. Dairy Sci. 70:1325-1330

Douillard, R. 1973. Rheological analysis of curd formation. J. Texture Stud. 4:158-165.

Douillard, R. 1986. A kinetic-model for protease-induced milk clotting and curdling. Lebenson. Wiss. Technol. 19:202-207.

Esteve, C. L. C., J. A. Lucey, and E. M. W. Pires. 2001. Mathematical modeling of the formation of rennet-induced gels by plant coagulants and chymosin. J. Dairy Res. 68:499-510.

Fagan, C. C., M. Castillo, F. A. Payne, C. P. O'Donnell, M. Leedy, and D. J. O'Callaghan. 2007a. Novel technology for continuous monitoring of milk coagulation and whey separation in cheesemaking. J. Agric. Food Chem. 55:8836-8844

Fagan, C. C., C. Everard, C. P. O'Donnell, G. Downey, E. M. Sheehan, C. M. Delahunty, and D. J. O'Callaghan. 2007b. Evaluating midinfrared spectroscopy as a new technique for predicting sensory texture attributes of processed cheese. J. Dairy Sci. 90:1122-1132.

Frederiksen, P. D., K. K. Andersen, M. Hammersh øj, H. D. Poulsen, J. Sørensen, M. Bakman, K. B. Qvist, and L. B. Larsen. 2011. Composition and effect of blending of noncoagulating, poorly coagulating, and well-coagulating bovine milk from individual Danish Holstein cows. J. Dairy Sci. 94:4787-4799.

Georges, M., D. Nielsen, M. Mackinnnon, A. Mishara, R. Okimoto, A. T. Pasquino, L. S. Sargeant, A. Sorensen, M. R. Steele, and X. Zhao. 1995. Mapping quantitative trait loci controlling milk production in dairy cattle by exploiting progeny testing. Genetics 139:907-920.

Gervais, A., and O. Cerf. 1983. Comparison of two models for fitting rennet-induced milk coagulation kinetics. J. Texture Stud. 14:47-59.

Glantz, M., T. G. Devold, G. E. Vegarud, H. Lindmark Månsson, H. Stålhammar, and M. Paulsson. 2010. Importance of casein mi- 
celle size and milk composition for milk gelation. J. Dairy Sci. 93:1444-1451.

Glantz, M., H. Lindmark Månsson, H. Stålhammar, and M. Paulsson. 2011. Effect of polymorphisms in the leptin, leptin receptor, and acyl-coenzyme A:diacylglycerol acyltransferase 1 (DGAT1) genes and genetic polymorphism of milk proteins on cheese characteristics. J. Dairy Sci. 94:3295-3304.

Glantz, M., H. L. Månsson, M. Paulsson, and H. Stålhammar. 2012 Genomic selection in relation to bovine milk composition and processability. J. Dairy Res. 79:53-59.

Glantz, M., H. L. Månsson, H. Stålhammar, L.-O. Bårström, M Fröjelin, A. Knutsson, C. Teluk, and M. Paulsson. 2009. Effects of animal selection on milk composition and processability. J. Dairy Sci. 92:4589-4603

Grandison, A. S., M. Anderson, G. D. Ford, and L. Newell. 1985. Interrelationships between the diet fed to cows, composition and properties of milk and composition and quality of Cheshire cheese from farmhouse manufacturers. J. Dairy Res. 52:587-593.

Hallen, E., T. Allmere, J. Naslund, A. Andren, and A. Lunden. 2007. Effect of genetic polymorphism of milk proteins on rheology of chymosin-induced milk gels. Int. Dairy J. 17:791-799.

Harzia, H., K. Kilk, I. Jõudu, M. Henno, O. Kärt, and U. Soomets, 2012. Comparison of the metabolic profiles of noncoagulating and coagulating bovine milk. J. Dairy Sci. 95:533-540.

Heck, J. M. L., A. Schennink, H. J. F. van Valenberg, H. Bovenhuis, M. H. P. W. Visker, J. A. M. van Arendonk, and A. C. M. van Hooijdonk. 2009. Effects of milk protein variants on the protein composition of bovine milk. J. Dairy Sci. 92:1192-1202.

Hurtaud, C., J. L. Peyraud, G. Michel, D. Berthelot, and L. Delaby 2009. Winter feeding systems and dairy cow breed have an impact on milk composition and flavor of two Protected Designation of Origin French cheeses. Animal 3:1327-1338.

Ibeagha-Awemu, E. M., P. Kgwatalala, and X. Zhao. 2008. A critical analysis of production-associated DNA polymorphisms in the genes of cattle, goat, sheep, and pig. Mamm. Genome 19:591-617. http://dx.doi.org/10.1007/s00335-008-9141-x.

Ikonen, T., K. Ahlfors, R. Kempe, M. Ojala, and O. Ruottinen. 1999a. Genetic parameters for the milk coagulation properties and prevalence of noncoagulating milk in Finnish dairy cows. J. Dairy Sci. $82: 205-214$.

Ikonen, T., H. Bovenhuis, M. Ojala, O. Ruottinen, and M. Georges. 2001. Associations between casein haplotypes and first lactation milk production traits in Finnish Ayrshire cows. J. Dairy Sci. 84:507-514.

Ikonen, T., S. Morri, A.-M. Tyrisevä, O. Ruottinen, and M. Ojala 2004. Genetic and phenotypic correlations between milk coagulation properties, milk production traits, somatic cell count, casein content, and pH of milk. J. Dairy Sci. 87:458-467.

Ikonen, T., M. Ojala, and O. Ruottinen. 1999c. Associations between milk protein polymorphism and first lactation milk production traits in Finnish Ayrshire. J. Dairy Sci. 82:1026-1033.

Ikonen, T., M. Ojala, and E.-L. Syväoja. 1997. Effects of composite casein and $\beta$-lactoglobulin genotypes on renneting properties and composition of bovine milk by assuming an animal model. Agric. Food Sci. Finl. 6:283-294.

Ikonen, T., O. Ruottinen, E.-L. Syväoja, K. Saarinen, E. Pahkala, and M. Ojala. 1999b. Effect of milk coagulation properties of herd bulk milks on yield and composition of Emmental cheese. Agric. Food Sci. Finl. 8:411-422.

International Dairy Federation. 2011. The world dairy situation. Bulletin 451/2011. International Dairy Federation, Brussels, Belgium.

Jakob, E., and Z. Puhan. 1992. Technological properties of milk as influenced by genetic polymorphism of milk proteins-A review. Int. Dairy J. 2:157-178.

Jakob, M., D. Jaros, and H. Rohm. 2011. Recent advances in milk clotting enzymes. Int. J. Dairy Technol. 64:14-33.

Jensen, H. B., J. W. Holland, N. A. Poulsen, and L. B. Larsen. 2012. Milk protein variants and isoforms identified in bovine milk representing extremes in coagulation properties. J. Dairy Sci. 95:28912903
Johnson, M. E., C. M. Chen, and J. J. Jaeggi. 2001. Effect of rennet coagulation time on composition, yield, and quality of reduced-fat Cheddar cheese. J. Dairy Sci. 84:1027-1033.

Jõudu, I., M. Henno, T. Kaart, T. Püssa, and O. Kärt. 2008. The effect of milk protein contents on the rennet coagulation properties of milk from individual dairy cows. Int. Dairy J. 18:964-967.

Jõudu, I., M. Henno, S. Värv, T. Kaart, and O. Kärt. 2007. Milk protein genotypes and milk coagulation properties of Estonian Native cattle. Agric. Food Sci. 16:222-231.

Jõudu, I., M. Henno, S. Värv, H. Viinalass, T. Püssa, T. Kaart, D. Arney, and O. Kärt. 2009. The effect of milk proteins on milk coagulation properties in Estonian dairy breeds. Vet. Zootec. 46:14-19.

Kaart, T., M. Vallas, A. Waldmann, H. Kiiman, K. Pärna, and E. Pärna. 2010. Associations between milk quality traits and coagulation properties and fertility in Estonian Holstein heifers and first lactation cows. Abstract 0567 in Proc. 9th World Congr. Genet. Appl. Livest. Prod. (WCGALP), Leipzig, Germany.

Klandar, A. H., A. Lagaude, and D. Chevalier-Lucia. 2007. Assessment of the rennet coagulation of skim milk: A comparison of methods. Int. Dairy J. 17:1151-1160.

Komisarek, J., and Z. Dorynek. 2006. The relationship between the T945M single nucleotide polymorphism in the leptin receptor gene (LEPR) and milk production traits in Jersey cows. Anim. Sci. Pap. Rep. 24:271-277.

Kowalchyk, A. W., and N. F. Olson. 1977. Effect of temperature on the secondary phase of milk clotting by rennet. J. Dairy Sci 60:1256-1259

Kreuzer, M., A. M. von Siebenthal, A. Kaufmann, H. Ratzer, E. Jakob, and F. Sutter. 1996. Determination of the relative efficacy to enhance milk renneting properties of alterations in dietary energy, breed and stage of lactation. Milchwissenschaft 51:633-637.

Kübarsepp, I., M. Henno, T. Kaart, E. Pärna, H. Viinalass, and D. Sabre. 2006. Frequencies of $\kappa-\mathrm{Cn}$ and $\beta-\mathrm{Lg}$ genetic variants among Estonian cattle breeds and their effect on the milk renneting properties. Abstract 01-65 in Proc. 8th World Congr. Genet. Appl. Livest. Prod. (WCGALP), Belo Horizonte, Brazil.

Kübarsepp, I., M. Henno, O. Kart, and T. Tupasela. 2005. A comparison of the methods for determination of the rennet coagulation properties of milk. Acta Agric. Scand. A Anim. Sci. 55:145-148.

Laporte, M.-F., R. Martel, and P. Paquin. 1998. The near-infrared optic probe for monitoring rennet coagulation in cow's milk. Int Dairy J. 8:659-666.

Lindström, U. B., V. Antila, and J. Syväjärvi. 1984. A note on some genetic and non-genetic factors affecting clotting time of Ayrshire milk. Acta Agric. Scand. 34:349-355.

Lodes, A., J. Buchberger, I. Krause, J. Aumann, and H. Kloster-Meyer. 1996a. The influence of genetic variants of milk proteins on the compositional and technological properties of milk. 2. Rennet coagulation time and firmness of the rennet curd. Milchwissenschaft 51:543-548.

Lodes, A., I. Krause, J. Buchberger, J. Aumann, and H. Kloster-Meyer. 1996b. The influence of genetic variants of milk proteins on the compositional and technological properties of milk. 1. Casein micelle size and the content of non-glycosylated $\kappa$-casein. Milchwissenschaft 51:368-373.

Macheboeuf, D., J. B. Coulon, and P. D'Hour. 1993a. Effect of breed, protein genetic variants and feeding on cow's milk coagulation properties. J. Dairy Res. 60:43-54.

Macheboeuf, D., J. B. Coulon, and P. D'Hour. 1993b. Aptitude a la coagulation du lait de vache. Influence de la race, des variants genetiques des lactoproteines du lait, de l'alimentation et du numero de lactation. Prod. Anim. 6:333-344.

Malacarne, M. S. Fieni, F. Tosi, P. Franceschi, P. Formaggioni, and A. Summer. 2005. Seasonal variations of the rennet-coagulation properties of herd milks in Parmigiano-Reggiano cheese manufacture: Comparison between Italian Friesian and Italian Brown cattle breeds. Ital. J. Anim. Sci. 4(Suppl. 2):242-244.

Malacarne, M., A. Summer, E. Fossa, P. Formaggioni, P. Franceschi, M. Pecorari, and P. Mariani. 2006. Composition, coagulation properties and Parmigiano-Reggiano cheese yield of Italian Brown and Italian Friesian herd milks. J. Dairy Res. 73:171-177. 
Malossini, F., S. Bovolenta, C. Piras, M. Dalla Rosa, and W. Ventura. 1996. Effect of diet and breed on milk composition and rennet coagulation properties. Ann. Zootech. 45:29-40.

Mantovani, R., M. De Marchi, N. Cologna, N. Guzzo, and G. Bittante. 2011. Breed housing and feeding systems affect milk coagulation traits and cheese yield and quality. Book of Abstracts of the 62nd Annual meeting of the European Federation of Animal Science, Stavanger, Norway.

Mariani, P., and B. Battistotti. 1999. Milk quality for cheesemaking. Recent Progress in Animal Production Science. 1. Pages 499-516 in Proc. APSA XIII Congress, Piacenza, Italy. Franco Angeli s.r.l., Milan, Italy.

Mariani, P., M. Pecorari, and E. Fossa. 1984. Le caratteristiche di coagulazione del latte delle razze Bruna e Frisona nella produzione del formaggio Parmigiano-Reggiano. Pages 319-327 in Atti del XVI Congresso Nazionale della Società Italiana di Buiatria (SIB). SIB, Modena, Italy.

Mariani, P., P. Serventi, and E. Fossa. 1997. Contenuto di caseina, varianti genetiche ed attitudine tecnologico casearia del latte delle vacche di razza Bruna nella produzione del formaggio grana. Allegato a La Razza Bruna Italiana 2:8-14.

Martin, B., J.-F. Chamba, J.-B. Coulon, and E. Perreard. 1997. Effect of milk chemical composition and clotting characteristics on chemical and sensory properties of Reblochon de Savoie cheese. J. Dairy Res. 64:157-162.

Martin, B., D. Pomiès, P. Pradel, I. Verdier-Metz, and B. Remond. 2009. Yield and sensory properties of cheese made with milk from Holstein or Montbeliarde cows milked twice or once daily. J. Dairy Sci. 92:4730-4737.

Marziali, A. S., and K. F. Ng-Kwai-Hang. 1986. Effects of milk composition and genetic polymorphism on coagulation properties of milk. J. Dairy Sci. 69:1793-1798.

Maurmayr, A., C. Ribeca, A. Cecchinato, M. Penasa, M. De Marchi, and G. Bittante. 2011. Effects of stearoyl-CoA desaturase 1 and sterol regulatory element binding protein gene polymorphisms on milk production, composition and coagulation properties of individual milk of Brown Swiss cows. Agric. Conspec. Sci. 76:235-237.

Mayer, H. K., M. Ortner, E. Tschager, and W. Ginzinger. 1997. Composite milk protein phenotypes in relation to composition and cheesemaking properties of milk. Int. Dairy J. 7:305-310.

McMahon, D. J., and R. J. Brown. 1982. Evaluation of Formagraph for comparing rennet solutions. J. Dairy Sci. 65:1639-1642.

McMahon, D. J., and R. J. Brown. 1984. Enzymatic coagulation of casein micelles: A review. J. Dairy Sci. 67:919-929.

McMahon, D. J., G. H. Richardson, and R. J. Brown. 1984. Enzymic milk coagulation: Role of equations involving coagulation time and curd firmness in describing coagulation. J. Dairy Sci. 67:11851193.

Medhammar, E., R. Wijesinha-Bettoni, B. Stadlmayr, E. Nilsson, U. R. Charrondiere, and B. Burlingame. 2012. Composition of milk from minor dairy animals and buffalo breeds: A biodiversity perspective. J. Sci. Food Agric. 92:445-474. http://dx.doi. org/10.1002/jsfa.4690.

Nájera, A. I., M. de Renobales, and L. I. R. Barron. 2003. Effects of $\mathrm{pH}$, temperature, $\mathrm{CaCl}_{2}$ and enzyme concentrations on the rennetclotting properties of milk: A multifactorial study. Food Chem. 80:345-352.

Ng-Kwai-Hang, K. F., J. F. Hayes, J. E. Moxley, and H. G. Monardes. 1987. Variation in milk protein concentrations associated with genetic polymorphism and environmental factors. J. Dairy Sci. $70: 563-570$.

Ng-Kwai-Hang, K. F., I. Politis, R. I. Cue, and A. S. Marziali. 1989. Correlations between coagulation properties of milk and cheese yielding capacity and cheese composition. Can. Inst. Food Sci. Technol. 22:291-294.

O'Callaghan, D. J., and T. P. Guinee. 1996. Comparison of mathematical models applied to rennet coagulation of skim milks. J. Texture Stud. 26:607-633.

O'Callaghan, D. J., C. P. O'Donnell, and F. A. Payne. 2002. Review of systems for monitoring curd setting during cheesemaking. Int. J. Dairy Technol. 55:65-74.
Ogorevc, J., T. Kunej, A. Razpet, and P. Dovc. 2009. Database of cattle candidate genes and genetic markers for milk production and mastitis. Anim. Genet. 40:832-851.

Ojala, M., A.-M. Tyrisevä, and T. Ikonen. 2005. Genetic improvement of milk quality traits for cheese production. Pages 307-311 in Indicators of Milk and Beef Quality. J. F. Hocquette and S. Gigli, ed. EAAP publication 112. Wageningen Academic Publishers, Wageningen, the Netherlands.

Okigbo, L. M., G. H. Richardson, R. J. Brown, and C. A. Ernstrom. 1985a. Variation in coagulation properties of milk from individual cows. J. Dairy Sci. 68:822-828.

Okigbo, L. M., G. H. Richardson, R. J. Brown, and C. A. Ernstrom. 1985b. Coagulation properties of abnormal and normal milk from individual cow quarters. J. Dairy Sci. 68:1893-1896.

Okigbo, L. M., G. H. Richardson, R. J. Brown, and C. A. Ernstrom. 1985c. Effects of $\mathrm{pH}$, calcium chloride, and chymosin concentration on coagulation properties of abnormal and normal milk. J. Dairy Sci. 68:2527-2533.

Okigbo, L. M., G. H. Richardson, R. J. Brown, and C. A. Ernstrom. 1985d. Interactions of calcium, $\mathrm{pH}$, temperature, and chymosin during milk coagulation. J. Dairy Sci. 68:3135-3142.

Oloffs, K., H. Shulte-Coerne, K. Pabst, and H. O. Gravert. 1992. Die Bedeutung der Proteinvarianten für genetische Unterschiede in der Käsereitauglichkeit der Milch. Züchtungskunde 64:20-26.

Pagnacco, G., and A. Caroli. 1987. Effect of casein and $\beta$-lactoglobulin genotypes on renneting properties of milks. J. Dairy Res. 54:479485

Park, Y. W., M. Juarez, M. Ramos, and G. F. W. Haenlein. 2007. Physico-chemical characteristics of goat and sheep milk. Small Rumin. Res. 68:88-113.

Penasa, M., M. Cassandro, D. Pretto, M. De Marchi, A. Comin, S. Chessa, R. Dal Zotto, and G. Bittante. 2010. Short communication: Influence of composite casein genotypes on additive genetic variation of milk production traits and coagulation properties in Holstein-Friesian cows. J. Dairy Sci. 93:3346-3349.

Politis, I., and K. F. Ng-Kwai-Hang. 1988. Effects of somatic cell counts and milk composition on the coagulating properties of milk. J. Dairy Sci. 71:1740-1746.

Pomiès, D., B. Martin, Y. Chilliard, P. Pradel, and B. Remond. 2007. Once-a-day milking of Holstein and Montbeliarde cows for 7 weeks in mid-lactation. Animal 1:1497-1505.

Potena, A., R. Napolano, G. Galiero, A. Coletta, R. Di Palo, G. Neglia, and L. Zicarelli. 2007a. Relationship between lactodynamographic and characteristics of buffalo milk. Ital. J. Anim. Sci. 6(Suppl. 2):1084-1087.

Potena, A., L. Zicarelli, R. Napolano, G. Iovane, G. Campanile, B. Gasparrini, and R. Di Palo. 2007b. Milk and curd characteristics depending on farm and production level. Ital. J. Anim. Sci. 6(Suppl. 2):1104-1107.

Riddell-Lawrence, S., and C. L. Hicks. 1989. Effect of curd firmness on stirred curd cheese yield. J. Dairy Sci. 72:313-321.

Saccà, E., S. Bovolenta, W. Ventura, and G. Gaiarin. 2003. Coagulation properties and Nostrano di Primiero cheese yield from Brown grazing cows of different $\kappa$-casein genotype. Ital. J. Anim. Sci. 2(Suppl. 1):284-286.

Schaar, J. 1984. Effects of $\kappa$-casein genetic variants and lactation number on the renneting properties of individual milks. J. Dairy Res. 51:397-406.

Schennink, A., W. M. Stoop, M. H. P. W. Visker, J. M. L. Heck, H. Bovenhuis, J. J. van der Poel, H. J. F. van Valenberg, and J. A. M. van Arendonk. 2007. DGAT1 underlies large genetic variation in milk-fat composition of dairy cows. Anim. Genet. 38:467-473.

Summer, A., P. Franceschi, A. Bollini, P. Formaggioni, F. Tosi, and P. Mariani. 2003. Seasonal variations of milk characteristics and cheesemaking losses in the manufacture of Parmigiano-Reggiano cheese. Vet. Res. Commun. 27(Suppl. 1):663-666.

Sundekilde, U. K., P. D. Frederiksen, M. R. Clausen, L. B. Larsen, and H. C. Bertram. 2011. Relationship between the metabolite profile and technological properties of bovine milk from two dairy breeds elucidated by NMR-based metabolomics. J. Agric. Food Chem. 59:7360-7367. 
Tervala, H.-L., V. Antila, and J. Syväjärvi. 1985. Factors affecting the renneting properties of milk. Meijeritieteellinen Aikakauskirja XLIII 1:16-25.

Tyrisevä, A.-M., K. Elo, A. Kuusipuro, V. Vilva, I. Jänönen, H. Karjalainen, T. Ikonen, and M. Ojala. 2008. Chromosomal regions underlying non-coagulation of milk in Finnish Ayrshire cows. Genetics 180:1211-1220.

Tyrisevä, A.-M., T. Ikonen, and M. Ojala. 2003. Repeatability estimates for milk coagulation traits and non-coagulation of milk in Finnish Ayrshire cows. J. Dairy Res. 70:91-98.

Tyrisevä, A.-M., T. Vahlsten, O. Ruottinen, and M. Ojala. 2004 Noncoagulation of milk in Finnish Ayrshire and Holstein-Friesian cows and effect of herds on milk coagulation ability. J. Dairy Sci. 87:3958-3966

Vallas, M., H. Bovenhuis, T. Kaart, K. Parna, H. Kiiman, and E. Pärna. 2010. Genetic parameters for milk coagulation properties in Estonian Holstein cows. J. Dairy Sci. 93:3789-3796.

van den Berg, G., J. T. M. Escher, P. J. de Koning, and H. Bovenhuis. 1992. Genetic polymorphism of $\kappa$-casein and $\beta$-lactoglobulin in relation to milk composition and processing properties. Neth. Milk Dairy J. 46:145-168.
Vera, R. R., C. Aguilar, and R. Lira. 2009. Differentiation of sheep milk and cheese based on quality and composition. Ciencia e Investigación Agraria 36:307-328.

Verdier-Metz, I., J. B. Coulon, P. Pradel, C. Viallon, and J. L. Berdague. 1998. Effect of forage conservation (hay or silage) and cow breed on the coagulation properties of milks and on the characteristics of ripened cheeses. J. Dairy Res. 65:9-21.

Walsh, C. D., T. P. Guinee, W. D. Reville, D. Harrington, J. J. Murphy, B. T. O'Kennedy, and R. J. Fitzgerald. 1998. Influence of k-casein genetic variant on rennet gel microstructure, Cheddar cheesemaking properties and casein micelle size. Int. Dairy J. 8:707-714

Wedholm, A., L. B. Larsen, H. Lindmark-Mansson, A. H. Karlsson, and A. Andren. 2006. Effect of protein composition on the cheesemaking properties of milk from individual dairy cows. J. Dairy Sci. 89:3296-3305.

Zannoni, M., and S. Annibaldi. 1981. Standardization of the renneting ability of milk by Formagraph. Sci. Tecn. Latt. Cas. 32:79-94.

Zicarelli, L. 2004. Buffalo milk: Its properties, dairy yield and Mozzarella production. Vet. Res. Commun. 28:127-135. 